\title{
Trace element transport in western Siberian rivers across a permafrost gradient
}

\author{
Oleg S. Pokrovsky ${ }^{1,2,3}$, Rinat M. Manasypov ${ }^{2,3}$, Sergey V. Loiko ${ }^{2}$, Ivan A. Krickov ${ }^{2}$, Sergey G. Kopysov ${ }^{2,4}$, \\ Larisa G. Kolesnichenko ${ }^{2}$, Sergey N. Vorobyev ${ }^{2}$, and Sergey N. Kirpotin ${ }^{2}$ \\ ${ }^{1}$ GET UMR5563 CNRS University of Toulouse (France), 14 Avenue Edouard Belin, 31400 Toulouse, France \\ ${ }^{2}$ BIO-GEO-CLIM Laboratory, Tomsk State University, Lenina av., 36, Tomsk, Russia \\ ${ }^{3}$ Institute of Ecological Problem of the North, 23 Nab Severnoi Dviny, Arkhangelsk, Russia \\ ${ }^{4}$ Institute of Monitoring of Climatic and Ecological Systems, SB RAS, Tomsk, Russia \\ Correspondence to: Oleg S. Pokrovsky (oleg@get.obs-mip.fr)
}

Received: 31 August 2015 - Published in Biogeosciences Discuss.: 10 November 2015

Revised: 11 March 2016 - Accepted: 16 March 2016 - Published: 30 March 2016

\begin{abstract}
Towards a better understanding of trace element (TE) transport in permafrost-affected Earth surface environments, we sampled $\sim 60$ large and small rivers $(<100$ to $\leq 150000 \mathrm{~km}^{2}$ watershed area) of the Western Siberian Lowland (WSL) during spring flood and summer and winter baseflow across a $1500 \mathrm{~km}$ latitudinal gradient covering continuous, discontinuous, sporadic and permafrost-free zones. Analysis of $\sim 40$ major and TEs in the dissolved $(<0.45 \mu \mathrm{m})$ fraction allowed establishing main environmental factors controlling the transport of metals and TEs in rivers of this environmentally important region. No statistically significant effect of the basin size on most TE concentrations was evidenced. Two groups of elements were distinguished: (1) elements that show the same trend throughout the year and (2) elements that show seasonal differences. The first group included elements decreasing northward during all seasons ( $\mathrm{Sr}, \mathrm{Mo}, \mathrm{U}, \mathrm{As}, \mathrm{Sb}$ ) marking the underground water influence of river feeding. The elements of the second group exhibited variable behavior in the course of the year. A northward increase during spring period was mostly pronounced for $\mathrm{Fe}, \mathrm{Al}, \mathrm{Co}, \mathrm{Zn}$ and $\mathrm{Ba}$ and may stem from a combination of enhanced leaching from the topsoil and vegetation and bottom waters of the lakes (spring overturn). A springtime northward decrease was observed for $\mathrm{Ni}, \mathrm{Cu}$, $\mathrm{Zr}$ and $\mathrm{Rb}$. The increase in element concentration northward was observed for $\mathrm{Ti}, \mathrm{Ga}, \mathrm{Zr}$ and $\mathrm{Th}$ only in winter, whereas $\mathrm{Fe}, \mathrm{Al}$, rare earth elements (REEs), $\mathrm{Pb}, \mathrm{Zr}$, and $\mathrm{Hf}$ increased northward in both spring and winter, which could be linked to leaching from peat and transport in the form of Fe-rich col-
\end{abstract}

loids. A southward increase in summer was strongly visible for $\mathrm{Fe}, \mathrm{Ni}, \mathrm{Ba}, \mathrm{Rb}$ and $\mathrm{V}$, probably due to peat/moss release $(\mathrm{Ni}, \mathrm{Ba}, \mathrm{Rb})$ or groundwater feeding $(\mathrm{Fe}, \mathrm{V})$. Finally, $\mathrm{B}, \mathrm{Li}$, $\mathrm{Cr}, \mathrm{V}, \mathrm{Mn}, \mathrm{Zn}, \mathrm{Cd}$, and $\mathrm{Cs}$ did not show any distinct trend from $\mathrm{S}$ to $\mathrm{N}$.

The order of landscape component impact on TE concentration in rivers was lakes $>$ bogs $>$ forest. The lakes decreased export of $\mathrm{Mn}$ and $\mathrm{Co}$ in summer and $\mathrm{Ni}, \mathrm{Cu}$, and $\mathrm{Rb}$ in spring, presumably due to biotic processes. The lakes enriched the rivers in insoluble lithogenic elements in summer and winter, likely due to TE mobilization from unfrozen mineral sediments. The rank of environmental factors on TE concentration in western Siberian rivers was latitude (three permafrost zones) $>$ season $>$ watershed size. The effect of the latitude was minimal in spring for most TEs but highly visible for $\mathrm{Sr}, \mathrm{Mo}, \mathrm{Sb}$ and $\mathrm{U}$. The main factors controlling the shift of river feeding from surface and subsurface flow to deep underground flow in the permafrost-bearing zone were the depth of the active (unfrozen) seasonal layer and its position in organic or mineral horizons of the soil profile. In the permafrost-free zone, the relative role of carbonate mineralbearing base rock feeding versus bog water feeding determined the pattern of TE concentration and fluxes in rivers of various sizes as a function of season.

Comparison of obtained TE fluxes in WSL rivers with those of other subarctic rivers demonstrated reasonable agreement for most TEs; the lithology of base rocks was the major factor controlling the magnitude of TE fluxes. Climate change in western Siberia and permafrost boundary migra- 
tion will essentially affect the elements controlled by underground water feeding (DIC, alkaline earth elements $(\mathrm{Ca}, \mathrm{Sr})$, oxyanions (Mo, Sb, As) and U). The thickening of the active layer may increase the export of trivalent and tetravalent hydrolysates in the form of organo-ferric colloids. Plant litter-originated divalent metals present as organic complexes may be retained via adsorption on mineral horizon. However, due to various counterbalanced processes controlling element source and sinks in plant-peat-mineral soil-river systems, the overall impact of the permafrost thaw on TE export from the land to the ocean may be smaller than that foreseen with merely active layer thickening and permafrost boundary shift.

\section{Introduction}

Trace element (TE) transport by rivers is the main factor controlling biogeochemical cycles of essential micronutrients ( $\mathrm{Fe}, \mathrm{Zn}, \mathrm{Ni}, \mathrm{Mn}, \mathrm{Mo}$ ), geochemical traces ( $\mathrm{Sr}$, rare earth elements (REEs)) and contaminants ( $\mathrm{Cd}, \mathrm{Pb}$, As etc.) at the Earth's surface. Whereas the majority of large rivers are systematically (Cooper et al., 2008; McClelland et al., 2015) or occasionally (Gordeev et al., 1996; Seyler et al., 2003; Pokrovsky et al., 2010; Gaillardet et al., 2014) monitored for some TE concentration and fluxes, this is not the case for smaller rivers, unless these rivers are affected by anthropogenic activity or local pollution. Because, in the permafrost zone, the size of the watershed determines the degree of groundwater feeding, river-specific discharge and water residence time (i.e., Nikitin and Zemtsov, 1986; Novikov et al., 2009), the effect of the river size on TE transport becomes an issue of high academic and practical importance. This may become especially relevant for testing various models of chemical weathering and element migration in the critical zone of the Arctic and subarctic (i.e., Beaulieu et al., 2012). However, straightforward comparison of element concentrations and fluxes in watersheds of various sizes is possible only in pristine regions of homogeneous runoff and landscape types (equatorial forest, tundra, or boreal biome of the platforms), where the seasonal aspect is often hard to resolve due to the difficulty of year-round access to the river or the lack of hydrological background.

In this regard, the orographically flat, lithologically homogeneous, peat-covered Western Siberia Lowland (WSL) offers a unique chance for testing various aspects of riverine element transport in a relatively pristine region with reasonably good knowledge of hydrology and runoff across a very large gradient of climate and vegetation. A very important aspect of western Siberian rivers is the dominance of peat soils, producing high concentrations of dissolved organic matter (DOM) of allochthonous (humic and fulvic) character. In the presence of dissolved organics, many typically insoluble, low-mobility elements, notably trivalent and tetravalent hydrolysates and some divalent metals, become highly labile when present as organic or organo-mineral colloids, i.e., entities between $1 \mathrm{kDa}(\sim 1 \mathrm{~nm})$ and $0.45 \mu \mathrm{m}$ (Stolpe et al., 2013; Porcelli et al., 1997). This colloidal form of migration greatly enhances the fluxes of TEs from the soil to the river and, finally, to the ocean. As a result, even small rivers of this region may turn out to be very important vectors of TE fluxes.

At present, the interest to aqueous geochemistry of major and trace elements in permafrost-affected regions is rising due to high vulnerability of these regions to climate change and the possibility of release of solutes previously stored in frozen soils and ice (see Anticibor et al., 2014; MacMillan et al., 2015; Vonk et al., 2015). This is particularly true for the WSL, which exhibits (i) highly unstable permafrost, mostly sporadic and discontinuous, and (ii) a large stock of frozen organic matter (peat horizons), potentially containing elevated concentrations of many metals $(\mathrm{Cu}, \mathrm{Zn}, \mathrm{Ni}, \mathrm{Pb}$, $\mathrm{Cd}, \mathrm{Ba}$ ) accumulated in peat. In this regard, the WSL allows for study of the mobilization of organic-bound metals from frozen soil to the river across more than $1500 \mathrm{~km}$ gradient of permafrost coverage (absent, sporadic, isolated, discontinuous and continuous), vegetation (southern and middle taiga to tundra) and climate $\left(0\right.$ to $-9{ }^{\circ} \mathrm{C}$ MAAT) while remaining within relatively homogeneous nature of underlining lithology (sands and clays), soils (peat and podzols) and runoff ( 200 to $300 \mathrm{~mm} \mathrm{yr}^{-1}$ ). Note that, in contrast to extensive studies of TEs in rivers and streams of boreal regions of Scandinavia (Ingri et al., 2000, 2005; Wallstedt et al., 2010; Huser et al., 2011, 2012; Oni et al., 2013; Tarvainen et al., 1997; Lidman et al., 2011, 2012, 2014; Temnerud et al., 2013), Alaska (Rember and Trefry, 2004), Canada (Wadleigh et al., 1985; Gaillardet et al., 2003; Millot et al., 2003), central Siberia (Pokrovsky et al., 2006; Bagard et al., 2011, 2013) and European Russia, 2010; Vasyukova et al., 2010), even punctual measurements of TEs in watersheds of large western Siberian rivers (Ob, Nadym, Taz and Pur basins) with the exceptions of the $\mathrm{Ob}$ and Irtush rivers (Moran and Woods, 1997; Alexeeva et al., 2001; Gordeev et al., 2004) are lacking. Moreover, similar to other Siberian rivers (Pokrovsky et al., 2006; Huh and Edmond, 1999; Huh et al., 1998; Dessert et al., 2009) seasonally resolved measurements of TEs in WSL rivers are absent. At the same time, monthly monitoring of large Arctic rivers at the terminal gauging stations (Holmes et al., 2000, 2012, 2013) provides neither a sufficient number of TE measurements nor information on smaller tributaries located within various climate and permafrost context.

Therefore, the general objective of this study was first the assessment of TE concentrations and fluxes across significant gradients of permafrost in the WSL. Specific tasks were the following: (i) quantifying the effect of the watershed area (or river discharge) and landscape components (bogs, lakes and forest) on TE concentration, (ii) assessing the difference of element concentration during main hydrological seasons (spring flood, summer and winter baseflow), (iii) revealing 
annual TE fluxes in rivers as a function of watershed latitude, and (iv) evaluating the degree of flux modification under a climate warming scenario comprising active layer thickness increase and northward migration of the permafrost boundary.

As a working hypothesis, and following the concepts developed for major element transport in WSL rivers (Frey et al., 2007a, b; Frey and McClelland, 2009; Frey and Smith, 2005; Pokrovsky et al., 2015), we expect that northward decrease in riverine fluxes and concentrations of elements is due to decrease in the groundwater which carries the signature of water-rock interaction below the soil active layer. At the same time, the elements bound to organic colloids can be preferentially mobilized from surface (organic-rich) horizons in permafrost-affected regions compared to permafrostfree regions. The increase in TE fluxes in the permafrost zone relative to the permafrost-free zone may be linked to limited downward migration of TE-DOM complexes and their low retention on frozen mineral horizon in the northern part of the WSL, as is reported for DOC (Kawahigashi et al., 2004; Pokrovsky et al., 2015). On the other hand, the presence of unfrozen mineral horizon in the south may enhance lithogenic element mobilization from the soil to the river. Therefore, three distinct families of TEs are expected in terms of the latitudinal pattern of their concentration and fluxes: (i) increasing northward, (ii) decreasing northward and (iii) independent of the latitude. This study aims at verifying the existence of these patterns and characterizing possible mechanisms of element mobilization using rigorous statistics for a large number of rivers sampled during main hydrological periods.

\section{Study site and methods}

\subsection{Physico-geographical setting}

The Western Siberian Lowland (WSL) includes the watersheds of the rivers Ob, Pur, Nadym and Taz as well as left tributaries of the Yenisei River draining Pliocene sands and clays. These sedimentary deposits are covered by thick (1 to $3 \mathrm{~m}$ ) peat and enclose boreal taiga, forest-tundra and tundra biomes. The thickness of Quaternary clays, sands, and silts ranges from several meters to $200-250 \mathrm{~m}$. The Paleogene and Neogene deposits are rarely exposed on the earth surface and are represented by sands, alevrolites and clays. In the southern part of the WSL, carbonate concretions and shells are present within the claystone and siltstones (Geological Composition, 1958). The mean annual temperature (MAT) ranges from $-0.5^{\circ} \mathrm{C}$ in the south (Tomsk region) to $-9.5^{\circ} \mathrm{C}$ in the north (Yamburg) with annual precipitation of $400 \pm 30$ (SD) $\mathrm{mm}$ over $1500 \mathrm{~km}$ latitudinal and permafrost gradient. The river runoff gradually increases northward, from $190 \pm 30$ (SD) $\mathrm{mm} \mathrm{yr}^{-1}$ in the permafrost-free Tomskaya region to $300 \pm 20$ (SD) $\mathrm{mm} \mathrm{yr}^{-1}$ in the discon- tinuous to continuous permafrost zone (Nikitin and Zemtsov, 1986). Further physico-geographical description, hydrology, lithology and soils can be found in Botch et al. (1995), Smith et al. (2004), Frey and Smith (2007), Beilman et al. (2009) and more recent studies of Shirokova et al. (2013), Manasypov et al. $(2014,2015)$ and Stepanova et al. (2015). A map of the studied region together with main permafrost provenances, bedrock lithology, active (seasonally unfrozen) layer depth, and river runoff in the WSL is given in Fig. 1. A more detailed river description and localization of watersheds are presented in Pokrovsky et al. (2015). Table 1 presents the list of sampled rivers with the main physico-geographical parameters of the watersheds.

The mean multi-annual monthly discharges of WSL rivers are available from systematic surveys of the Russian Hydrological Survey (Hydrological Yearbooks of RHS), generalized in Nikitin and Zemtsov (1986) and also compiled in the R-AcricNET database (www.r-arcticnet.sr.unh.edu). In this study, due to the limited number of observations over the year, the river discharge for each river was averaged for each of the three seasons of sampling (May to June, July to September, and October to April). In addition, a systematic hydrological study of the State Hydrological Institute in 1973-1992 in the northern part of western Siberia allowed reliable evaluation of small and medium rivers' discharges (Novikov et al., 2009). Details of small WSL rivers' discharge calculations are presented in as previous publication (Pokrovsky et al., 2015).

The proportion of bogs, lakes and forest coverage of the river watersheds was numerically assessed via digitalizing GIS-based landscape maps of western Siberia $(1: 200000$ scale). For large and medium rivers that have RHS gauging stations, information on the watershed coverage was collected from Zhil and Alushkinskaya (1972). Evaluation of the degree of permafrost distribution on river watersheds was possible thanks to available geocryological maps of western Siberia (1 : 500 000; see Ershov, 1989; Yastrebov and Ivanov, 2008).

\subsection{Sampling and analyses}

We sampled 70 rivers in early June 2013 and 2014 (spring flood), 67 rivers in August 2013 and 2014 (summer baseflow), 13 rivers in October 2013 (autumn) and 55 rivers in February 2014 (winter baseflow); see Table S1 in the Supplement. The sampling points were located some 100-200 m upstream of where the river crossed the regional road. The traffic on WSL roads is quite low and thus the pollution from the road is expected to be minimal. Several tests were made during summer baseflow on the same rivers sampled at different distances from the road bridge. Regardless of the size of the river, with the watershed ranging from a few square kilometers to $10000 \mathrm{~km}^{2}$, this test did not yield any statistically significant difference $(p>0.05)$ in the concentration of all TEs. The watershed area of the sampled rivers ranged from 
Table 1. List of sampled rivers, their watershed area, annual runoff, landscape parameters of the watershed (\% of bogs, lakes and forest coverage), lithology (\% of sand, loam and clay; the rest is peat) and permafrost coverage. The numbers in the first column represent the rivers in the map (Fig. 1). Rivers 27 (Medvedka), 30 (Alenkin Egan), 35 (Er-Yakh), 66 (Khanupiyakha), 33 (Mokhovaya), 74 (Etu-Yakha), 77 (Kharv'-Yakha), 31 (Kaima) and 65 (Pulpuyakha) are influenced by industrial oil activities (18, 20, 11, 6, 3, 2, 2, 1 and 1\% of watershed, respectively). Rivers 29 (Mishkin Saim), 3 (Chubyr'), 4 (Shegarka), 10 (Chemondaevka), 11 (Sugotka), 5 (Brovka), 8 (Malyi Tatosh), 2 (Prud), 20 (Vyalovka) and 16 (Chigas) are affected by agricultural activity (61, 51, 40, 38, 30, 30, 25, 17, 14 and 13\% of watershed, respectively). Rivers 14 (Istok) and 13 (Tatarkin istok) are within the Ob River flooding zone with meadow vegetation (14 and $12 \%$ of watershed, respectively). The lithology of watersheds 92 (Malokha Yakha), 93 (Nuny-Yakha) and 95 (Khadutte) is represented by the interlayer mixture of sand, loam and clays (66, 76 and $84 \%$, respectively). ND stands for non-determined.

\begin{tabular}{|c|c|c|c|c|c|c|c|c|c|c|}
\hline River & $\mathrm{N}$ & $\mathrm{E}$ & $\begin{array}{l}\text { Watersheds, } \\
\mathrm{km}^{2}\end{array}$ & $\begin{array}{l}\text { Annual runoff, } \\
\mathrm{mm} \mathrm{yr}^{-1}\end{array}$ & $\begin{array}{r}\text { S bogs, } \\
\%\end{array}$ & $\begin{array}{r}\mathrm{S} \text { forest, } \\
\%\end{array}$ & $\begin{array}{l}\text { S lakes, } \\
\%\end{array}$ & $\begin{array}{c}\text { S sand, } \\
\%\end{array}$ & $\begin{array}{c}\text { S loam, } \\
\%\end{array}$ & $\begin{array}{c}\mathrm{S} \text { permafrost, } \\
\%\end{array}$ \\
\hline 27. Medvedka & $60^{\circ} 44^{\prime} 10.9^{\prime \prime}$ & $77^{\circ} 22^{\prime} 55.9^{\prime \prime}$ & 7 & 173 & 36.2 & 45.3 & 0 & 64 & 0 & 0 \\
\hline 81. Tydylyakha & $65^{\circ} 06^{\prime} 48.8^{\prime \prime}$ & $77^{\circ} 47^{\prime} 58.8^{\prime \prime}$ & 7.46 & 185 & 49.4 & 37.4 & 12.7 & 51 & 0 & 49 \\
\hline 3. Chubyr' & $56^{\circ} 43^{\prime} 15.0^{\prime \prime}$ & $83^{\circ} 55^{\prime} 35.1^{\prime \prime}$ & 8.14 & 44.8 & 19.9 & 28.4 & 1.01 & 0 & 80 & 0 \\
\hline 35. Er-Yakh & $61^{\circ} 12^{\prime} 19.5^{\prime \prime}$ & $75^{\circ} 23^{\prime} 06.5^{\prime \prime}$ & 9.35 & 173 & 60.7 & 33.5 & 0.0 & 40 & 0 & 0 \\
\hline 42. Vachinguriyagun & $61^{\circ} 50^{\prime} 28.6^{\prime \prime}$ & $73^{\circ} 50^{\prime} 28.2^{\prime \prime}$ & 9.52 & 192 & 78.7 & 9.4 & 11.9 & 21 & 0 & 0 \\
\hline 47. Pertriyagun & $62^{\circ} 37^{\prime} 08.4^{\prime \prime}$ & $74^{\circ} 10^{\prime} 15.9^{\prime \prime}$ & 9.65 & 192 & 57.2 & 6.7 & 36.1 & 43 & 0 & 5 \\
\hline 60. Goensapur & $63^{\circ} 12^{\prime} 43.38^{\prime \prime}$ & $76^{\circ} 21^{\prime} 27.66^{\prime \prime}$ & 11 & 194 & 53.2 & 40.2 & 6.6 & 47 & 0 & 25 \\
\hline 82. Tydyotta & $65^{\circ} 12^{\prime} 17.6^{\prime \prime}$ & $77^{\circ} 43^{\prime} 49.8^{\prime \prime}$ & 12.0 & 309 & 53.0 & 43.0 & 4.0 & 47 & 0 & 25 \\
\hline 14. Istok & $58^{\circ} 24^{\prime} 38.0^{\prime \prime}$ & $82^{\circ} 08^{\prime} 46.0^{\prime \prime}$ & 12.3 & 127 & 12.7 & 72.1 & 3.12 & 0 & 87 & 0 \\
\hline 61. Denna & $63^{\circ} 12^{\prime} 45.96^{\prime \prime}$ & $76^{\circ} 24^{\prime} 1.32^{\prime \prime}$ & 15 & 194 & 69.2 & 18.8 & 12.0 & 31 & 0 & 35 \\
\hline 78. Seryareyakha & $64^{\circ} 32^{\prime} 07.9^{\prime \prime}$ & $76^{\circ} 54^{\prime} 21.3^{\prime \prime}$ & 15.2 & 186 & 61.2 & 19.4 & 19.4 & 39 & 0 & 60 \\
\hline 73. Apoku-Yakha & $64^{\circ} 09^{\prime} 06.4^{\prime \prime}$ & $75^{\circ} 22^{\prime} 18.1^{\prime \prime}$ & 18.8 & 186 & 75.5 & 12.8 & 11.7 & 24 & 0 & 38 \\
\hline 54. Ponto-Yakha & $63^{\circ} 9^{\prime} 31.38^{\prime \prime}$ & $75^{\circ} 3^{\prime} 2.58^{\prime \prime}$ & 19 & 194 & 66.3 & 29.9 & 3.8 & 34 & 0 & 33 \\
\hline 43. Lyukh-Yagun & $61^{\circ} 58^{\prime} 05.1^{\prime \prime}$ & $73^{\circ} 47^{\prime} 03.4^{\prime \prime}$ & 21.6 & 192 & 62.2 & 17.9 & 19.5 & 38 & 0 & 0 \\
\hline 49. Ai-Kirill-Vys'yagun & $62^{\circ} 43^{\prime} 09.9^{\prime \prime}$ & $74^{\circ} 13^{\prime} 45.9^{\prime \prime}$ & 24.0 & 192 & 52.3 & 36.7 & 10.1 & 48 & 0 & 10 \\
\hline 28. Saim & $60^{\circ} 45^{\prime} 58.5^{\prime \prime}$ & $77^{\circ} 26^{\prime} 12.6^{\prime \prime}$ & 26 & 173 & 48.4 & 48.4 & 3.2 & 50 & 0 & 0 \\
\hline 31. Kaima & $60^{\circ} 50^{\prime} 43.6^{\prime \prime}$ & $77^{\circ} 05^{\prime} 03.0^{\prime \prime}$ & 31 & 173 & 55.2 & 43.5 & 0.0 & 0 & 45 & 0 \\
\hline 6. Cherniy Klyuch & $56^{\circ} 54^{\prime} 39.1^{\prime \prime}$ & $82^{\circ} 33^{\prime} 33.3^{\prime \prime}$ & 32 & 168 & 40.6 & 59.84 & 0.1 & 0 & 59 & 0 \\
\hline 29. Mishkin Saim & $60^{\circ} 47^{\prime} 29.3^{\prime \prime}$ & $77^{\circ} 19^{\prime} 13.5^{\prime \prime}$ & 32 & 173 & 25.5 & 13.4 & 0.59 & 47 & 0 & 0 \\
\hline 67. Nyudya-Itu-Yakha & $63^{\circ} 8^{\prime} 34.02^{\prime \prime}$ & $74^{\circ} 54^{\prime} 29.1^{\prime \prime}$ & 32 & 194 & 55.9 & 35.7 & 8.4 & 44 & 0 & 11 \\
\hline 46. Pintyr' yagun & $62^{\circ} 33^{\prime} 39.8^{\prime \prime}$ & $74^{\circ} 00^{\prime} 29.5^{\prime \prime}$ & 33.5 & 192 & 61 & 0 & 39.0 & 39 & 0 & 8 \\
\hline 64. Khatytayakha & $63^{\circ} 36^{\prime} 48.2^{\prime \prime}$ & $74^{\circ} 35^{\prime} 28.6^{\prime \prime}$ & 34.6 & 194 & 75.3 & 13.2 & 10.8 & 25 & 0 & 38 \\
\hline 88. Tadym-Yakha & $65^{\circ} 59^{\prime} 05.7^{\prime \prime}$ & $77^{\circ} 40^{\prime} 52.6^{\prime \prime}$ & 39.9 & 185 & 75.1 & 2.82 & 22.08 & 25 & 0 & 30 \\
\hline 87. Yude-Yakha & $65^{\circ} 58^{\prime} 54^{\prime \prime}$ & $77^{\circ} 34^{\prime} 05^{\prime \prime}$ & 42.4 & 185 & 69.43 & 2.42 & 28.15 & 31 & 0 & 35 \\
\hline 57. Tlyatsayakha & $63^{\circ} 13^{\prime} 25.2^{\prime \prime}$ & $76^{\circ} 5^{\prime} 23.04^{\prime \prime}$ & 43 & 194 & 52.8 & 38 & 9.2 & 47 & 0 & 27 \\
\hline 30. Alenkin Egan & $60^{\circ} 49^{\prime} 32.3^{\prime \prime}$ & $77^{\circ} 1346.3^{\prime \prime}$ & 44 & 173 & 45.3 & 35.2 & 0.014 & 65 & 0 & 0 \\
\hline 77. Kharv'-Yakha & $64^{\circ} 26^{\prime} 05.2^{\prime \prime}$ & $76^{\circ} 24^{\prime} 37.0^{\prime \prime}$ & 46.4 & 186 & 32.9 & 58.1 & 7.27 & 67 & 0 & 17 \\
\hline 76. Khaloku-Yakha & $64^{\circ} 23^{\prime} 30.6^{\prime \prime}$ & $76^{\circ} 19^{\prime} 50.1^{\prime \prime}$ & 53 & 186 & 15.6 & 83.3 & 1.1 & 84 & 0 & 15 \\
\hline 13. Tatarkin Istok & $58^{\circ} 23^{\prime} 16.8^{\prime \prime}$ & $82^{\circ} 11^{\prime} 39.0^{\prime \prime}$ & 58.6 & 33.4 & 20.2 & 61.9 & 3.6 & 0 & 80 & 0 \\
\hline 71. Ngarka-Tyde-Yakha & $64^{\circ} 12^{\prime} 08.4^{\prime \prime}$ & $75^{\circ} 24^{\prime} 28.4^{\prime \prime}$ & 59.9 & 186 & 5.5 & 92.3 & 2.2 & 95 & 0 & 5 \\
\hline 2. Prud & $56^{\circ} 46^{\prime} 19.5^{\prime \prime}$ & $83^{\circ} 57^{\prime} 35.7^{\prime \prime}$ & 61.5 & 44.8 & 37.9 & 45.5 & 0.0 & 0 & 62 & 0 \\
\hline 72. Ngarka-Varka-Yakha & $64^{\circ} 06^{\prime} 50.7^{\prime \prime}$ & $75^{\circ} 14^{\prime} 17.3^{\prime \prime}$ & 67.1 & 186 & 52.1 & 32.6 & 15.3 & 48 & 0 & 26 \\
\hline 74. Etu-Yakha & $64^{\circ} 17^{\prime} 31.9^{\prime \prime}$ & $75^{\circ} 44^{\prime} 33.4^{\prime \prime}$ & 71.6 & 186 & 23.4 & 71.5 & 1.96 & 77 & 0 & 23 \\
\hline 66. Khanupiyakha & $63^{\circ} 49^{\prime} 58.0^{\prime \prime}$ & $74^{\circ} 39^{\prime} 02.5^{\prime \prime}$ & 74 & 194 & 21.4 & 66.4 & 0.91 & 79 & 0 & 10 \\
\hline 83. Ponie-Yakha & $65^{\circ} 23^{\prime} 34.1^{\prime \prime}$ & $77^{\circ} 45^{\prime} 46.7^{\prime \prime}$ & 78.9 & 185 & 66 & 17.7 & 16.3 & 34 & 0 & 70 \\
\hline 53.Nyudya-Pidya-Yakha & $63^{\circ} 10^{\prime} 4.68^{\prime \prime}$ & $76^{\circ} 28^{\prime} 19.08^{\prime \prime}$ & 79.5 & 194 & 61.3 & 38.1 & 0.6 & 39 & 0 & 30 \\
\hline 50. Pyrya-Yakha & $63^{\circ} 11^{\prime} 19.3^{\prime \prime}$ & $74^{\circ} 36^{\prime} 25.5^{\prime \prime}$ & 82 & 194 & 36.3 & 61.5 & 2.16 & 64 & 0 & 18 \\
\hline 56. Yangayakha & $63^{\circ} 13^{\prime} 12.06^{\prime \prime}$ & $75^{\circ} 38^{\prime} 52.26^{\prime \prime}$ & 88 & 194 & 67.1 & 19.7 & 13.2 & 33 & 0 & 19 \\
\hline 41. Vach-Yagun & $61^{\circ} 29^{\prime} 11.1^{\prime \prime}$ & $74^{\circ} 09^{\prime} 42.9^{\prime \prime}$ & 98.9 & 192 & 77.9 & 17.2 & 1.7 & 22 & 0 & 0 \\
\hline 40. Segut-Yagun & $61^{\circ} 29^{\prime} 46.6^{\prime \prime}$ & $74^{\circ} 15^{\prime} 30.3^{\prime \prime}$ & 110 & 192 & 81.1 & 7.2 & 8.6 & 19 & 0 & 0 \\
\hline 52. Nekhtyn-Pryn & $63^{\circ} 10^{\prime} 3.48^{\prime \prime}$ & $74^{\circ} 45^{\prime} 16.32^{\prime \prime}$ & 96 & 194 & 82 & 15.8 & 2.2 & 18 & 0 & 41 \\
\hline 75. Varka-Yakha & $64^{\circ} 19^{\prime} 10.1^{\prime \prime}$ & $76^{\circ} 08^{\prime} 26.7^{\prime \prime}$ & 105 & 186 & 47.3 & 50.5 & 2.2 & 53 & 0 & 23 \\
\hline 86. Almayakha & $65^{\circ} 47^{\prime} 48.6^{\prime \prime}$ & $78^{\circ} 10^{\prime} 09.0^{\prime \prime}$ & 106 & 185 & 76.3 & 4.2 & 19.5 & 24 & 0 & 76 \\
\hline 69. Lymbyd'yakha & $63^{\circ} 47^{\prime} 04.5^{\prime \prime}$ & $75^{\circ} 37^{\prime} 06.8^{\prime \prime}$ & 115 & 194 & 59.3 & 6.1 & 34.6 & 41 & 0 & 30 \\
\hline 20. Vyalovka & $58^{\circ} 40^{\prime} 46.5^{\prime \prime}$ & $84^{\circ} 27^{\prime} 56.6^{\prime \prime}$ & 117 & 127 & 37 & 48.4 & 0.19 & 0 & 63 & 0 \\
\hline 58. Chukusamal & $63^{\circ} 13^{\prime} 3.66^{\prime \prime}$ & $76^{\circ} 15^{\prime} 24.6^{\prime \prime}$ & 121 & 194 & 49.3 & 42.2 & 8.5 & 51 & 0 & 49 \\
\hline 92. Malokha Yakha & $66^{\circ} 59^{\prime} 20.9^{\prime \prime}$ & $79^{\circ} 22^{\prime} 30.5^{\prime \prime}$ & 157 & 208 & 34.0 & 64.2 & 1.8 & \multicolumn{2}{|c|}{66} & 98 \\
\hline 55. Velykh-Pelykh-Yakha & $63^{\circ} 9^{\prime} 39.84^{\prime \prime}$ & $75^{\circ} 09^{\prime} 10.86^{\prime \prime}$ & 170 & 194 & 28.6 & 69.7 & 1.7 & 71 & 0 & 15 \\
\hline 63. Kamgayakha & $63^{\circ} 22^{\prime} 01.6^{\prime \prime}$ & $74^{\circ} 31^{\prime} 53.2^{\prime \prime}$ & 175 & 194 & 23.7 & 76.2 & 0.1 & 76 & 0 & 12 \\
\hline 10. Chemondaevka & $57^{\circ} 52^{\prime} 26.8^{\prime \prime}$ & $83^{\circ} 11^{\prime} 29.9^{\prime \prime}$ & 177 & 63.4 & 10.4 & 49.6 & 0.037 & 0 & 90 & 0 \\
\hline 85. Khiroyakha & $65^{\circ} 46^{\prime} 34.5^{\prime \prime}$ & $78^{\circ} 08^{\prime} 25.8^{\prime \prime}$ & 183 & 185 & 59.8 & 10.7 & 28.6 & 40 & 0 & 60 \\
\hline 22. Kornilovskaya & $59^{\circ} 41^{\prime} 01.6^{\prime \prime}$ & $77^{\circ} 44^{\prime} 33.9^{\prime \prime}$ & 190 & 133 & 18.2 & 81.1 & 0.7 & 0 & 82 & 0 \\
\hline 24. Koltogorka & $60^{\circ} 08^{\prime} 43^{\prime \prime}$ & $77^{\circ} 16^{\prime} 53^{\prime \prime}$ & 220 & 155 & 9.66 & 90.3 & 0.04 & 0 & 90 & 0 \\
\hline 38. Kottym'egan & $61^{\circ} 27^{\prime} 17.3^{\prime \prime}$ & $74^{\circ} 40^{\prime} 23.3^{\prime \prime}$ & 236 & 192 & 77.6 & 12.0 & 10.4 & 22 & 0 & 0 \\
\hline 51. Itu-Yakha & $63^{\circ} 11^{\prime} 40.68^{\prime \prime}$ & $74^{\circ} 38^{\prime} 16.92^{\prime \prime}$ & 250 & 194 & 55.1 & 31.4 & 13.5 & 45 & 0 & 0 \\
\hline 23. Levyi Il'yas & $59^{\circ} 44^{\prime} 09.2^{\prime \prime}$ & $77^{\circ} 26^{\prime} 06^{\prime \prime}$ & 253 & 133 & 33.9 & 65.1 & 1.0 & 0 & 66 & 0 \\
\hline 11. Sugotka & $57^{\circ} 58^{\prime} 45.7^{\prime \prime}$ & $82^{\circ} 58^{\prime} 32.2^{\prime \prime}$ & 275 & 63.4 & 6.99 & 62.6 & 0.0 & 0 & 93 & 0 \\
\hline 65. Pulpuyakha & $63^{\circ} 40^{\prime} 41.8^{\prime \prime}$ & $74^{\circ} 35^{\prime} 20.7^{\prime \prime}$ & 281 & 194 & 27.8 & 61.8 & 9.28 & 72 & 0 & 15 \\
\hline 8. Malyi Tatosh & $57^{\circ} 36^{\prime} 43.3^{\prime \prime}$ & $83^{\circ} 37^{\prime} 02.1^{\prime \prime}$ & 302 & 63.4 & 7.89 & 66.9 & 0.085 & 0 & 92 & 0 \\
\hline
\end{tabular}


Table 1. Continued.

\begin{tabular}{|c|c|c|c|c|c|c|c|c|c|c|}
\hline River & $\mathrm{N}$ & $\mathrm{E}$ & $\begin{array}{l}\text { Watersheds, } \\
\mathrm{km}^{2}\end{array}$ & $\begin{array}{l}\text { Annual runoff, } \\
\mathrm{mm} \mathrm{yr}^{-1}\end{array}$ & $\begin{array}{r}\text { S bogs, } \\
\%\end{array}$ & $\begin{array}{r}\mathrm{S} \text { forest, } \\
\%\end{array}$ & $\begin{array}{l}\text { S lakes, } \\
\%\end{array}$ & $\begin{array}{c}\text { S sand, } \\
\%\end{array}$ & $\begin{array}{c}\text { S loam, } \\
\%\end{array}$ & $\begin{array}{c}\text { S permafrost, } \\
\%\end{array}$ \\
\hline 5. Brovka & $57^{\circ} 19^{\prime} 20.7^{\prime \prime}$ & $83^{\circ} 55^{\prime} 53.8^{\prime \prime}$ & 320 & 63.4 & 1.48 & 67.8 & 0.22 & 0 & 99 & 0 \\
\hline 36. Ur'evskii Egan & $61^{\circ} 19^{\prime} 41.2^{\prime \prime}$ & $75^{\circ} 04^{\prime} 0.3^{\prime \prime}$ & 359 & 272 & 60.7 & 36.3 & 3.0 & 39 & 0 & 0 \\
\hline 17. Karza & $58^{\circ} 32^{\prime} 05.8^{\prime \prime}$ & $80^{\circ} 51^{\prime} 26.8^{\prime \prime}$ & 473 & 148 & 34.3 & 65.6 & 0.1 & 0 & 66 & 0 \\
\hline 18. Sochiga & $58^{\circ} 37^{\prime} 29.9^{\prime \prime}$ & $81^{\circ} 06^{\prime} 09.0^{\prime \prime}$ & 510 & 148 & 27.7 & 72.3 & 0.0 & 0 & 72 & 0 \\
\hline 90. Mal. Khadyr-Yakha & $65^{\circ} 59^{\prime} 14.7^{\prime \prime}$ & $78^{\circ} 32^{\prime} 25.2^{\prime \prime}$ & 512 & 278 & 14.8 & 84.9 & 0.3 & 31 & 53 & 15 \\
\hline 48. Kirill-Vys'yagun & $63^{\circ} 38^{\prime} 23.4^{\prime \prime}$ & $74^{\circ} 10^{\prime} 52^{\prime \prime}$ & 598 & 225 & 62.1 & 11.8 & 26.1 & 38 & 0 & 12 \\
\hline 93. Nuny-Yakha & $67^{\circ} 10^{\prime} 54.8^{\prime \prime}$ & $78^{\circ} 51^{\prime} 04.5^{\prime \prime}$ & 656 & 312 & 24.3 & 37 & 3.05 & \multicolumn{2}{|c|}{76} & 24 \\
\hline 16. Chigas & $58^{\circ} 33^{\prime} 03.1^{\prime \prime}$ & $81^{\circ} 48^{\prime} 44.3^{\prime \prime}$ & 689 & 180 & 39.4 & 46.2 & 1.58 & 0 & 61 & 0 \\
\hline 25. Sosninskii Yegan & $60^{\circ} 30^{\prime} 19^{\prime \prime}$ & $76^{\circ} 58^{\prime} 57^{\prime \prime}$ & 732 & 199 & 19.5 & 80.4 & 0.1 & 0 & 81 & 0 \\
\hline 67. Kharucheiyakha & $63^{\circ} 51^{\prime} 23.4^{\prime \prime}$ & $75^{\circ} 08^{\prime} 05.6^{\prime \prime}$ & 820 & 292 & 44.6 & 54 & 1.4 & 55 & 0 & 44 \\
\hline 9. Bolshoy Tatosh & $57^{\circ} 37^{\prime} 17.3^{\prime \prime}$ & $83^{\circ} 31^{\prime} 53.3^{\prime \prime}$ & 1020 & 74.6 & 35.4 & 64.6 & 0.0 & 0 & 65 & 0 \\
\hline 33. Mokhovaya & $61^{\circ} 34^{\prime} 27.4^{\prime \prime}$ & $77^{\circ} 46^{\prime} 35.4^{\prime \prime}$ & 1260 & 192.3 & 32.2 & 64.0 & 1.9 & 68 & 0 & 0 \\
\hline 70. Chuchi-Yakha & $63^{\circ} 43^{\prime} 37.9^{\prime \prime}$ & $75^{\circ} 59^{\prime} 04.1^{\prime \prime}$ & 1396 & 292 & 52.8 & 44.2 & 3.0 & 47 & 0 & 26 \\
\hline 44. Limpas & $61^{\circ} 59^{\prime} 39^{\prime \prime}$ & $73^{\circ} 47^{\prime} 39^{\prime \prime}$ & 1648 & 320 & 59.5 & 11.2 & 29.3 & 40 & 0 & 12 \\
\hline 91. Ngarka Khadyta-Yakha & $66^{\circ} 17^{\prime} 10.8^{\prime \prime}$ & $79^{\circ} 15^{\prime} 06.1^{\prime \prime}$ & 1970 & 277 & 22.0 & 76.0 & 2.0 & 78 & 0 & 50 \\
\hline 59. Vyngapur & $63^{\circ} 46^{\prime} 22.92^{\prime \prime}$ & $76^{\circ} 25^{\prime} 28.86^{\prime \prime}$ & 1979 & 324 & 57.0 & 40.0 & 3.0 & 43 & 0 & 28 \\
\hline 7. Bakchar & $57^{\circ} 02^{\prime} 23.75^{\prime \prime}$ & $82^{\circ} 04^{\prime} 02.44^{\prime \prime}$ & 2040 & 96.1 & 39.3 & 60.5 & 0.2 & 0 & 61 & 0 \\
\hline 34. Vatinsky Egan & $61^{\circ} 11^{\prime} 52.7^{\prime \prime}$ & $75^{\circ} 25^{\prime} 20.2^{\prime \prime}$ & 3190 & 287 & 67.3 & 27.5 & 5.2 & 31 & 18 & 0 \\
\hline 15. Shudelka & $58^{\circ} 26^{\prime} 06.9^{\prime \prime}$ & $82^{\circ} 05^{\prime} 43.6^{\prime \prime}$ & 3460 & 211 & 68.2 & 31.8 & 0.0 & 0 & 32 & 0 \\
\hline 84. Yamsovey & $65^{\circ} 41^{\prime} 51.1^{\prime \prime}$ & $78^{\circ} 01^{\prime} 05.0^{\prime \prime}$ & 4030 & 309 & 53.7 & 38.7 & 7.5 & 46 & 0 & 54 \\
\hline 79. Purpe & $64^{\circ} 40^{\prime} 14.0^{\prime \prime}$ & $77^{\circ} 05^{\prime} 27.2^{\prime \prime}$ & 5110 & 309 & 48.0 & 34.0 & 15.0 & 52 & 0 & 48 \\
\hline 95. Khadutte & $67^{\circ} 24^{\prime} 39^{\prime \prime}$ & $76^{\circ} 21^{\prime} 12^{\prime \prime}$ & 5190 & 346 & 16.0 & 73.5 & 10.5 & \multicolumn{2}{|c|}{84} & 90 \\
\hline 68. Pyakupur & $63^{\circ} 49^{\prime} 54.2^{\prime \prime}$ & $75^{\circ} 22^{\prime} 47.1^{\prime \prime}$ & 9880 & 324 & 45.0 & 40.0 & 12.0 & 55 & 0 & 34 \\
\hline 45. Tromyegan & $62^{\circ} 07^{\prime} 50.0^{\prime \prime}$ & $73^{\circ} 44^{\prime} 05.6^{\prime \prime}$ & 10770 & 263 & 51.85 & 35.55 & 12.6 & 48 & 0 & 10 \\
\hline 4. Shegarka & $57^{\circ} 06^{\prime} 39.2^{\prime \prime}$ & $83^{\circ} 54^{\prime} 41.1^{\prime \prime}$ & 12000 & 58.3 & 19.7 & 41.4 & 1.1 & 0 & 80 & 0 \\
\hline 19. Parabel & $58^{\circ} 42^{\prime} 34.5^{\prime \prime}$ & $81^{\circ} 22^{\prime} 22.0^{\prime \prime}$ & 25500 & 131 & 69.4 & 28.8 & 0.8 & 0 & 31 & 0 \\
\hline 80. Aivasedapur & $64^{\circ} 55^{\prime} 55.1^{\prime \prime}$ & $77^{\circ} 56^{\prime} 08.2^{\prime \prime}$ & 26100 & 309 & 40.1 & 45.5 & 14.4 & 50 & 4 & 20 \\
\hline 12. Chaya & $58^{\circ} 04^{\prime} 20.8^{\prime \prime}$ & $82^{\circ} 49^{\prime} 19.7^{\prime \prime}$ & 27200 & 96 & 59.3 & 39.5 & 1.2 & 0 & 41 & 0 \\
\hline 37. Agan & $61^{\circ} 26^{\prime} 13.6^{\prime \prime}$ & $74^{\circ} 47^{\prime} 39.7^{\prime \prime}$ & 27600 & 291 & 46.9 & 42.5 & 10.6 & 35 & 10 & 5 \\
\hline 21. Vasyugan & $58^{\circ} 59^{\prime} 37^{\prime \prime}$ & $80^{\circ} 34^{\prime} 00^{\prime \prime}$ & 63780 & 177 & 66.9 & 31.4 & 1.7 & 5 & 95 & 0 \\
\hline 32. Vakh & $60^{\circ} 55^{\prime} 41.0^{\prime \prime}$ & $76^{\circ} 53^{\prime} 49.3^{\prime \prime}$ & 75090 & 298 & 35.0 & 61.0 & 4.0 & 46 & 18 & 5 \\
\hline 89. Pur & $65^{\circ} 57^{\prime} 05.5^{\prime \prime}$ & $78^{\circ} 18^{\prime} 59.1^{\prime \prime}$ & 112000 & 298 & 56.9 & 34.4 & 8.7 & 43 & 0 & 34 \\
\hline 94. Taz & $67^{\circ} 22^{\prime} 13.28^{\prime \prime}$ & $79^{\circ} 00^{\prime} 25.9^{\prime \prime}$ & 150000 & 330 & 38.0 & 59.0 & 3.0 & 62 & 0 & 40 \\
\hline 26. Ob' & $60^{\circ} 40^{\prime} 28.8^{\prime \prime}$ & $77^{\circ} 31^{\prime} 29.4^{\prime \prime}$ & 773200 & 216 & 10.0 & ND & ND & ND & ND & 0 \\
\hline 1. $\mathrm{Ob}$ & $56^{\circ} 31^{\prime} 48^{\prime \prime}$ & $84^{\circ} 09^{\prime} 44^{\prime \prime}$ & 423100 & 207 & 0.6 & ND & ND & ND & ND & 0 \\
\hline
\end{tabular}

2 to $150000 \mathrm{~km}^{2}$, excluding the $\mathrm{Ob}$ in its medium course zone. The water samples were collected from the middle of the stream for small rivers or at $0.5 \mathrm{~m}$ depth $1-2 \mathrm{~m}$ offshore on the large rivers using vinyl gloves and pre-washed polypropylene (PP) jars. Collected water samples were immediately filtered in cleaned $30 \mathrm{~mL}$ PP Nalgene ${ }^{\circledR}$ flacons through single-use pre-washed filter units (Minisart, Sartorius, acetate cellulose filter) with a diameter of $33 \mathrm{~mm}$ and a pore size of $0.45 \mu \mathrm{m}$. The first 20 to $50 \mathrm{~mL}$ of filtrate was discarded. Filtered solutions for trace analyses were acidified ( $\mathrm{pH} \sim 2$ ) with ultrapure double-distilled $\mathrm{HNO}_{3}$ and stored in the refrigerator. The preparation of bottles for sample storage was performed in a clean bench room (ISO A 10 000). Blanks of Milli-Q water were processed in the field in parallel to samples in order to control the level of pollution induced by sampling and filtration. For most TEs except Zn, these blanks were less than $10 \%$ of the element concentration in the sample. For several rivers in winter, the Zn blanks were 30 to $50 \%$ of their sample concentration; these data were not used in the discussion. Analyses of DOC, $\mathrm{pH}$, major cations and anions and their uncertainties are described in detail in a previous publication (Pokrovsky et al., 2015). Note that, in February, all rivers north of $66^{\circ} \mathrm{N}$, in the con- tinuous permafrost zone, except for the largest watershed, Khadutte $\left(4933 \mathrm{~km}^{2}\right)$, were completely frozen: under $1.5-$ $2 \mathrm{~m}$ ice thick, no water was found down to $20 \mathrm{~cm}$ of the frozen sand sediments at the river bed.

TEs were determined with an Agilent 7500ce inductively coupled plasma mass spectrometer with In and Re as internal standards and three various external standards, placed every 10 samples in a series of river water. SLRS-5 (Riverine Water Reference Material for Trace Metals certified by the National Research Council of Canada) was measured every 20 samples to check the accuracy and reproducibility of the analysis (Yeghicheyan et al., 2013). The typical agreement with certified values was better than $10 \%$ except for some elements ( $\mathrm{Ga}, \mathrm{Y}, \mathrm{W}, \mathrm{Th})$ that yielded 20 to $30 \%$ agreement. However, the analytical uncertainty on these element analyses was at least $20 \%$, so the agreement was considered acceptable. We also applied drift correction using an in-house EPOND standard or highly diluted BCR-482 digested lichen. Further details of TE analysis in boreal organic-rich surface waters, uncertainties and detection limits are presented in previous publications of our group (Pokrovsky et al., 2010, 2013; Shirokova et al., 2013; Manasypov et al., 2014, 2015). 

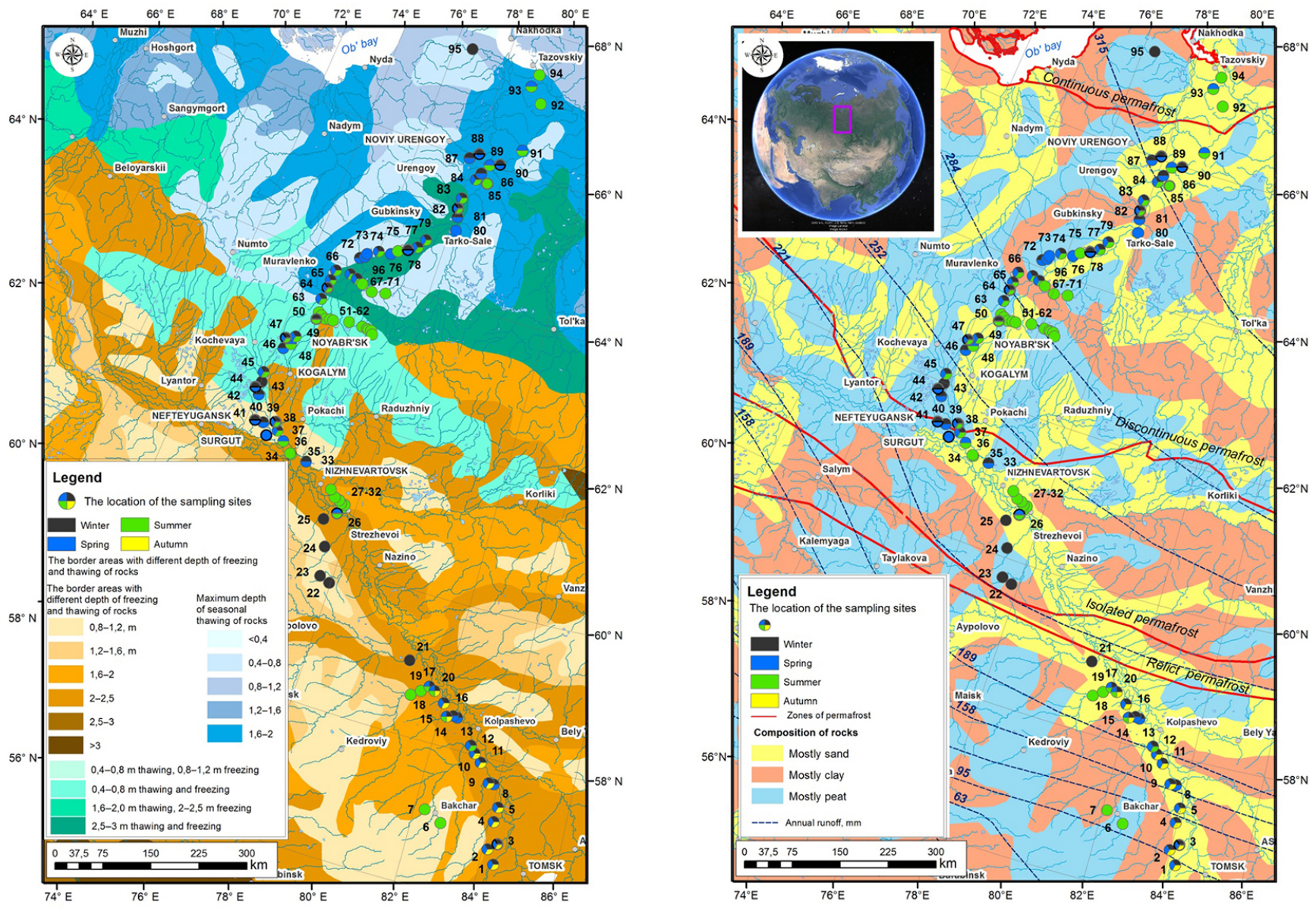

Figure 1. Scheme of sampled rivers in the Western Siberian Lowland (WSL) together with lithological information and thawing soil depth.

\subsection{Statistical treatment of the data and element speciation in the river water}

The concentrations of carbon and major elements in rivers were treated using the least-squares method, Pearson correlation and one-way ANOVA (SigmaPlot version 11.0, Systat Software, Inc.). Regressions and power functions were used to examine the relationships between TE concentration and the watershed area, latitude, and seasons. TE concentrations in rivers of (1) three main permafrost zones (continuous, discontinuous and permafrost-free regions), (2) six latitudinal classes of the watershed (56-58, 58-60, 60-62, 62-64, 64-66 and 66-68 N), (3) during three main seasons and (4) four watershed size classes $(<100,100-1000$, $1000-10000$, and $>10000 \mathrm{~km}^{2}$ ) were processed using nonparametric $H$-criterion Kruskal-Wallis test. This test is suitable for evaluation of difference of each TE among several samplings simultaneously. It is considered statistically significant at $p<0.05$. However, we found that a $p$ level of $<0.0001$ corresponding to $H>30$ indicated more significant differences and was thus also used in assessing the relative effect of season, latitude and watershed size.
Principal component analysis (PCA) was used to compute and interpret the spatial structures of TEs in rivers using the STATISTICA package (http://www.statsoft.com). This treatment was used for both the full set of sampled rivers for all seasons simultaneously and for each season individually. Both log-transformed and non-transformed data were used for analyses. Here, we considered the average latitude of the watershed and its watershed area, $\mathrm{pH}$, and all major and trace element concentration as numerical variables.

Metal speciation and complexation with DOM in the river water were modeled using visual Minteq code (version 3.1; Gustafsson, 2014). For vMinteq calculation, seasonaveraged major and TE concentrations of permafrost-free, discontinuous and continuous permafrost zone were used.

\section{Results}

\subsection{Pearson correlation coefficient and impact of lakes, bogs and forest on TEs in rivers}

A full data set of TE concentration in sampled rivers is available at the location given in the "Data availability" section 
below. The variability in TEs within each latitudinal range was the highest for small-size catchments $\left(<100 \mathrm{~km}^{2}\right)$. Pearson correlation coefficients of TEs with organic and inorganic carbon, $\mathrm{Fe}$ and $\mathrm{Al}$ are listed in Table S1. For these correlations, dissolved organic and inorganic carbon (DOC and $\mathrm{DIC}$, respectively), $\mathrm{Fe}$ and $\mathrm{Al}$ were chosen as main tracers of TE mobilization from surface and underground reservoirs and TE colloidal carriers in Siberian rivers and lakes, as their presence may limit the transport of heavy metals and hydrolysates in the form of high-molecular-weight organic and organo-mineral colloids (see Pokrovsky et al., 2006, 2012). On the other hand, DIC is the most efficient tracer of groundwater feeding of rivers and it reflects the water-rock interaction in the basement (Beaulieu et al., 2012; Tank et al., 2012). It can be seen from Table S1 that, during the open-water period (spring, summer and autumn), the DOC is statistically significantly $(p<0.05$ ) correlated with $\mathrm{Be}, \mathrm{Al}, \mathrm{Ti}, \mathrm{V}, \mathrm{Cr}, \mathrm{Ni}$, $\mathrm{Cu}, \mathrm{Ga}, \mathrm{Zr}, \mathrm{Nb}$, REEs (in summer and autumn), $\mathrm{Hf}$ and $\mathrm{Th}$, with the highest correlations always observed during summer. Several elements (Li, B, As, Sr, Mo, Sb, U) were more significantly correlated with DIC than DOC. In winter, only $\operatorname{Sr}(R=0.82)$ and $\mathrm{U} R=(0.80)$ were linked to DIC and none of the TEs was strongly $(R>0.60)$ correlated with DOC.

All insoluble, low-mobility TEs were highly correlated with Al. This was mostly pronounced during summer $(0.8 \leq R \leq 0.98)$ for $\mathrm{Be}, \mathrm{Ti}, \mathrm{Cr}, \mathrm{Co}, \mathrm{Ga}, \mathrm{Zr}, \mathrm{Cd}$, REEs and Th. The correlation of these elements with $\mathrm{Al}$ was also significant $(R>0.55$ at $p<0.05)$ in spring and autumn. The correlation of TEs with $\mathrm{Fe}$ was not statistically significant during all seasons except winter, when $\mathrm{Ti}, \mathrm{V}, \mathrm{Cr}, \mathrm{Mn}, \mathrm{Ga}$, As and $\mathrm{Zr}$ were correlated $(R>0.5, p<0.05)$ with $\mathrm{Fe}$, although the correlation coefficient of $\mathrm{Ti}, \mathrm{V}, \mathrm{Cr}$ and $\mathrm{Zr}$ was higher with $\mathrm{Al}$ than with Fe.

A correlation matrix between major and TE concentration and the percentage of lakes, bogs and forest on the watershed is given in Table S2. In spring, the bogs exhibited weak but significant anti-correlation $(-0.34 \leq R \leq-0.45)$ with specific conductivity (S.C.), pH, DIC, $\mathrm{Mg}, \mathrm{Si}, \mathrm{K}, \mathrm{Ca}, \mathrm{Ni}, \mathrm{Sr}$ and Mo. During this period, the lakes decrease $\mathrm{pH}, \mathrm{Si}, \mathrm{Ni}, \mathrm{Cu}$, $\mathrm{Rb}$ and $\mathrm{Th}$ concentrations in rivers $(-0.32 \leq R \leq-0.42)$, whereas the presence of forest increased the concentrations of $\mathrm{Si}, \mathrm{Mn}$ and $\mathrm{Co}(0.3 \leq R \leq 0.43)$. In summer, the lakes exhibited a negative correlation with $\mathrm{pH}$, S.C., DIC, B, Na, $\mathrm{Mg}, \mathrm{Si}, \mathrm{K}, \mathrm{Mn}$ and $\mathrm{Co}$ but a positive correlation with $\mathrm{Al}$, $\mathrm{Cu}, \mathrm{Cd}$, light REEs (LREEs) and $\mathrm{Pb}(0.42 \leq R \leq 0.57)$. Finally, in winter, the bogs exhibited positive correlation with $\mathrm{Al}$, Ti, $\mathrm{Cr}, \mathrm{Zr}, \mathrm{Pb}$ and $\mathrm{Th}(0.38 \leq R \leq 0.43)$, the lakes enhanced the concentrations of $\mathrm{Al}, \mathrm{Ti}, \mathrm{V}, \mathrm{Cr}, \mathrm{Fe}, \mathrm{Ga}, \mathrm{Zr}$, REEs, $\mathrm{Pb}$ and $\mathrm{Th}$, whereas the proportion of forest negatively correlated with concentration of these insoluble lithogenic elements. Overall, although the impact of landscape components is not greatly pronounced (significant correlation coefficients are between \pm 0.30 and \pm 0.45 ), it can be ranked in the order lakes $>$ bogs $>$ forest.
These preliminary links between TE carriers (DOC, Fe, $\mathrm{Al}$ ) or proxies (DIC) were further examined using PCA (Fig. S1 in the Supplement). The PCA demonstrated two main factors potentially controlling the ensemble of TE concentration variation. The first factor, responsible for 19-20\% of overall variation, included $\mathrm{Al}$, all trivalent and tetravalent hydrolysates, $\mathrm{Cr}, \mathrm{V}, \mathrm{Cd}$, and DOC and presumably reflected the presence of organo-mineral colloids, which are positively affected by the proportion of forest on the watershed. The second factor (8-10\% variation) was linked to the latitude of the watershed and acted on elements affected by the groundwater feeding (DIC, Sr, Mo, As, Sb, W, U), whose concentration decreased significantly northward during all seasons. During open-water periods, forest increased the export of mobile elements. The presence of bogs and lakes enhances the transport of insoluble lithogenic element in winter. The impact of the latitude was strongly pronounced during all seasons. One may notice high stability of general F1 $\times$ F2 structure during different seasons, although the effect of landscape units was much less visible during the winter when the latitude impacted the low-solubility elements $\mathrm{TE}^{3+}$ and $\mathrm{TE}^{4+}$ hydrolysates (Fig. S1). Note, however, that a straightforward discrimination of lakes, bogs and forest versus permafrost effects on element concentration in WSL rivers was not possible, because the proportion of lakes and bogs is much higher in the tundra and forest-tundra zone relative to the permafrost-free middle taiga zone.

In the presentation of results below, we will focus on a few distinct groups of similar elements according to their chemical properties (i.e., alkalis, alkaline earth elements, divalent metals, tri- and tetravalent hydrolysates, oxyanions and neutral molecules), following the similarity of element behavior in surface waters of western Siberia (e.g., Manasypov et al., 2014, 2015; Vorobyev et al., 2015). Special attention will be given to $\mathrm{Fe}$ and $\mathrm{Al}$, the major colloidal carriers whose concentration and transport essentially control the migration of all other trivalent and tetravalent hydrolysates in surface waters of western Siberia (Pokrovsky et al., 2011, 2013; Shirokova et al., 2013). Moreover, we analyzed in detail the behavior of $\mathrm{Sr}$, Mo and $\mathrm{U}$ because these elements are most affected by the permafrost abundance, or the latitudinal position of the watershed, which was the central issue of this study.

\subsection{TE concentration dependence on the average latitude of the watershed}

The concentration of TEs as a function of the watershed latitude is shown in Figs. 2-10 and S2 to S13 for three main hydrological seasons. Trivalent hydrolysates such as $\mathrm{Al}, \mathrm{Ga}$, $\mathrm{Y}$, and REEs demonstrate no link between concentration and latitude in spring and summer and a much higher increase (by a factor of 10 to 100) northward during winter (Figs. 3 and S2). Fe and the tetravalent hydrolysates $\mathrm{Ti}, \mathrm{Zr}$ and $\mathrm{Th}$ also demonstrated a significant $(p<0.05)$ northward increase 
in winter, the lack of a visible latitudinal trend in spring and a decrease in concentration northward in summer (Fig. 2 for $\mathrm{Fe}$ and $\mathrm{S} 3$ for $\mathrm{Ti}$ as an example). The divalent metals (Mn, $\mathrm{Zn}$, $\mathrm{Co}, \mathrm{Ni}, \mathrm{Cu}, \mathrm{Cd}$ and $\mathrm{Pb}$ ) yielded high variability in element concentration for the same latitudinal range, without a distinct latitudinal trend in summer and winter $(\mathrm{Mn}, \mathrm{Ni}, \mathrm{Co}, \mathrm{Cu}$, $\mathrm{Zn}, \mathrm{Pb}, \mathrm{Cd})$, an increase northward of concentration in spring $(\mathrm{Co}, \mathrm{Zn})$, and a decrease in spring $(\mathrm{Ni}, \mathrm{Cu})$. This is illustrated for $\mathrm{Mn}, \mathrm{Cu}, \mathrm{Zn}$ and $\mathrm{Pb}$ in Figs. 4-7 and for $\mathrm{Ni}, \mathrm{Co}$, and $\mathrm{Cd}$ in Figs. S4-S6. Cr showed a significant northward decrease in spring and increase in winter, without distinct latitudinal trend in summer (Fig. S7).

A number of elements exhibited very strong latitudinal trends regardless of the season and the watershed size. These are Sr (Fig. 8), Mo (Fig. 9) and U (Fig. 10). To a lesser degree, a seasonally persistent trend of northward concentration decrease is observed for B (summer and winter only, Fig. S8), As (Fig. S9) and $\mathrm{Sb}$ (not shown). A significant $(p<0.05)$ decrease in $\mathrm{Li}$ and $\mathrm{Rb}$ concentration in spring and $\mathrm{V}$ concentration in spring and summer was also visible for all watershed sizes (not shown). In contrast to $\mathrm{Sr}$, Ba concentration increased northward in spring, while it greatly decreased during summer (Fig. S10).

Statistical treatment of these trends is described in the next section.

\subsection{Statistical treatment of TE concentration in WSL rivers}

All sampled watershed were separated into four main classes of area: $<100 \mathrm{~km}^{2}, 100$ to $1000 \mathrm{~km}^{2}, 1000$ to $10000 \mathrm{~km}^{2}$ and $>10000 \mathrm{~km}^{2}$. Six latitude ranges were considered during the three main hydrological seasons (56 to 58,58 to 60,60 to 62,62 to 64,64 to 66 and 66 to $68^{\circ} \mathrm{N}$ ). The significance of TE concentrations' variations for each watershed size as a function of each latitudinal class was tested separately for each season and for the full period of observation.

\subsubsection{Effect of the watershed size and season}

Based on the $H$ criterion of Kruskal-Wallis, the differences between watersheds of different sizes were found to be quite low. In spring, only $\mathrm{Ti}, \mathrm{Ni}, \mathrm{Cu}, \mathrm{Ga}, \mathrm{Zr}$, REEs, $\mathrm{Pb}$, Th and $\mathrm{U}$ yielded a slight effect $(H<10-15$ and $p>0.001)$ of the size, whereas the concentrations of all other elements were statistically insensitive to the watershed area. In summer, a weak effect $(H \sim 10, p>0.01)$ was seen for $\mathrm{Al}, \mathrm{V}, \mathrm{Ni}, \mathrm{Cu}$, $\mathrm{Rb}$, Mo and $\mathrm{U}$ with only $\mathrm{Mn}$ and Co showing clear link to the size of the river $(H=18.5, p=0.0003 ; H=16.4$, $p=0.0009$, respectively). In winter, only $\mathrm{Al}$ showed a significant effect of watershed area $(H=21.8, p=0.0001)$, whereas $\mathrm{Ti}, \mathrm{V}, \mathrm{Cr}, \mathrm{Fe}, \mathrm{Sr}, \mathrm{Zr}$, Ba, REEs and $\mathrm{Pb}$ yielded a weak effect $(H<15, p<0.0001)$. Finally, considering all seasons together, only U yielded a significant impact of the watershed size $(H=30.2, p<0.0001)$, whereas all other elements had

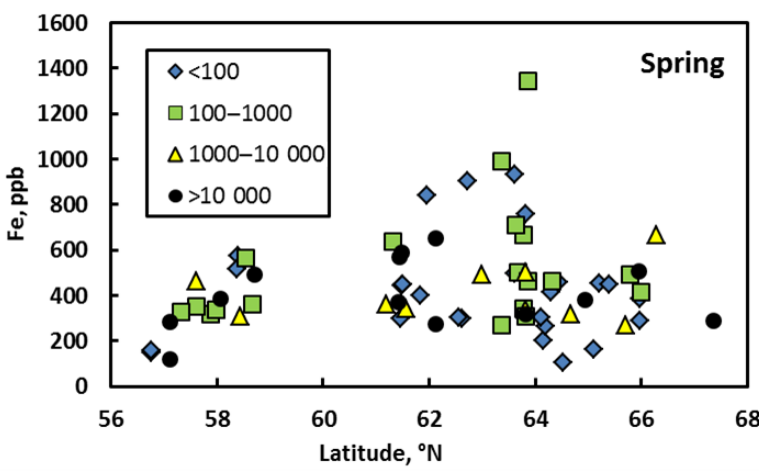

(a)

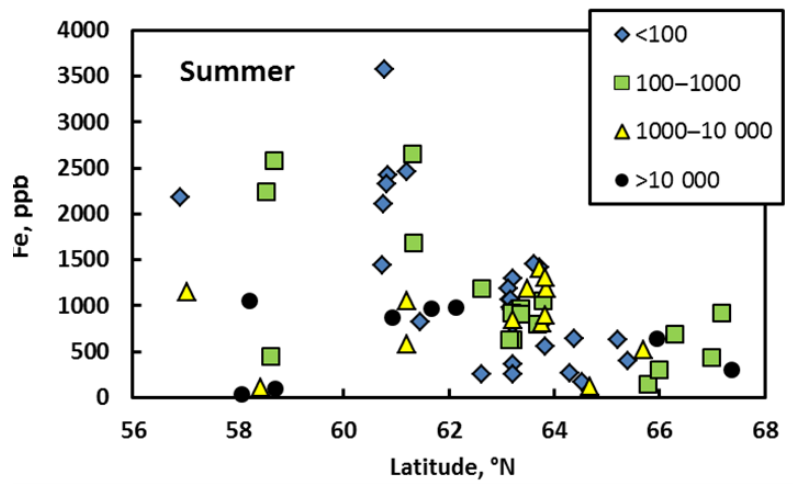

(b)

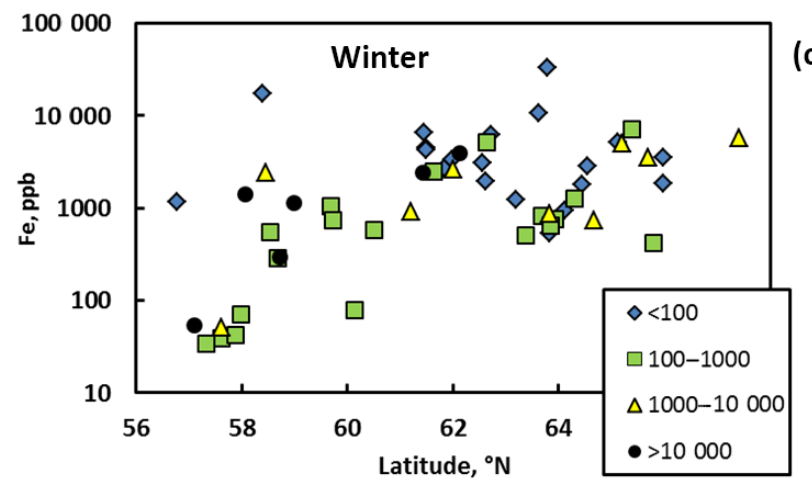

Figure 2. Variation in river water dissolved $\mathrm{Fe}$ with the increase in latitude during spring (a), summer (b) and winter (c). The variability among different watershed size is smaller than that between the seasons and within the latitude gradient. Diamonds, squares, triangles and circles represent watershed of size $<100 \mathrm{~km}^{2}, 100$ to $1000 \mathrm{~km}^{2}$, 1000 to $10000 \mathrm{~km}^{2}$, and $>10000 \mathrm{~km}^{2}$, respectively.

$H<20$ at $p>0.001$. The correlation matrix analysis demonstrated significant (at $p<0.05$ ) positive correlation of watershed area with $\mathrm{Mn}$ in spring, $\mathrm{V}$ in summer and $\mathrm{Cs}$ in winter ( $R=0.39,0.32$ and 0.35 , respectively). A negative correlation of watershed area with $\mathrm{Mn}$ and Co occurred in summer ( $R=-0.38$ and -0.36 , respectively).

The seasonal effects were tested for all river sizes and latitudes simultaneously. Generally, the seasonal TE concentration variations were more significantly pronounced than those of the watershed size. Considering all river sizes across 

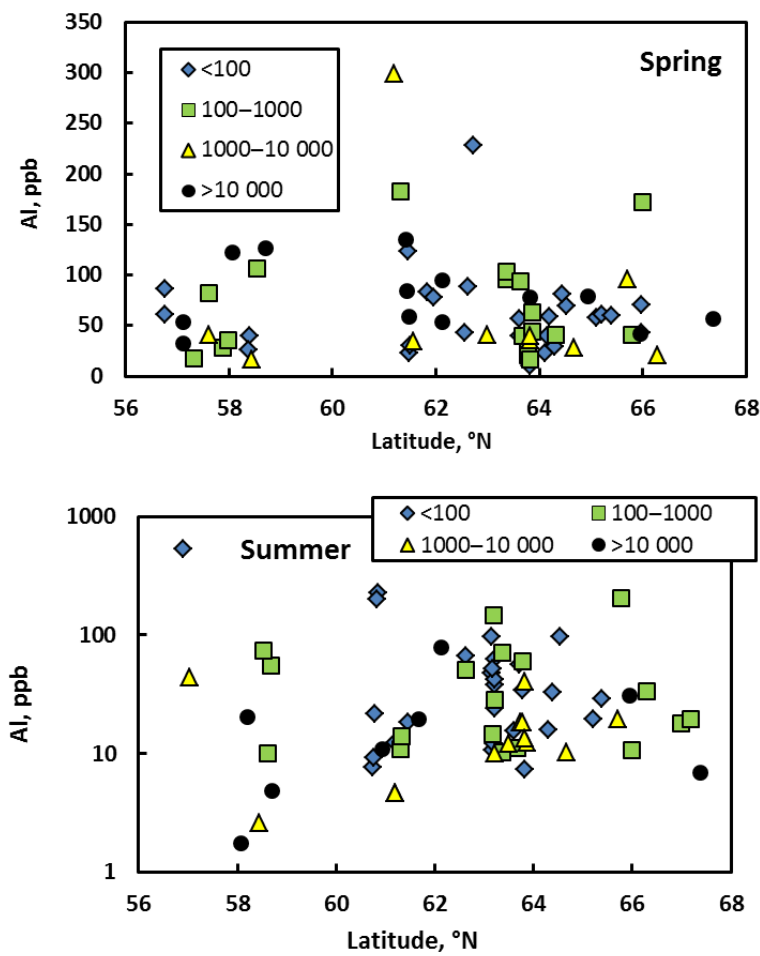

(b)
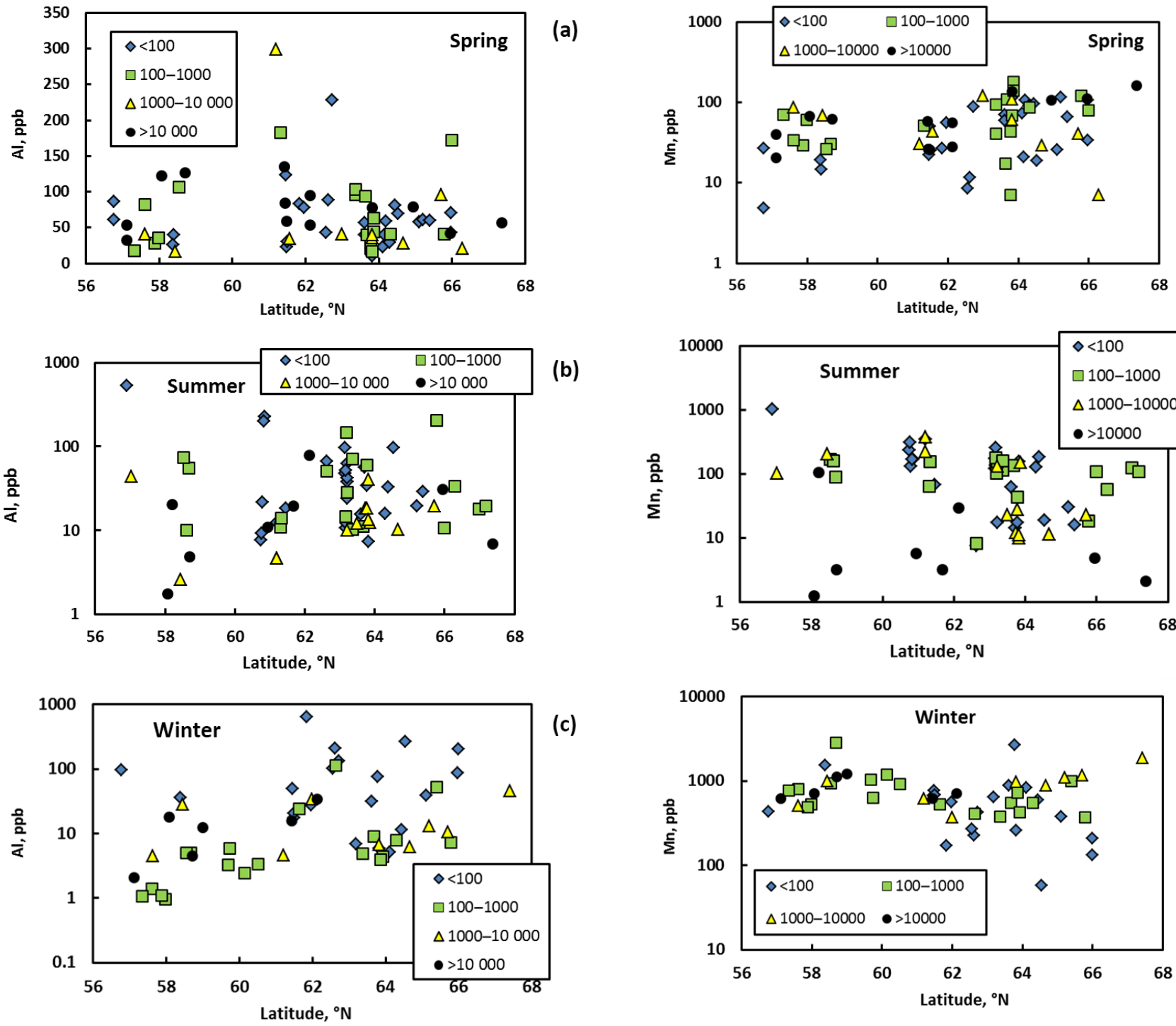

(a)
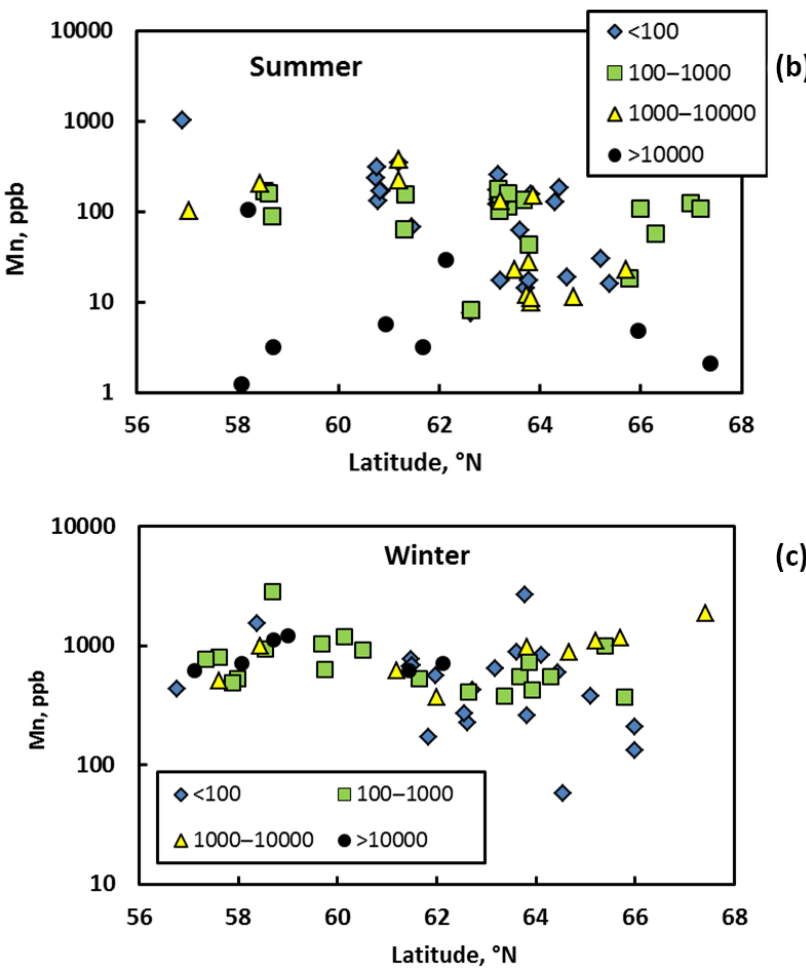

(c)

Figure 3. Variation in $\mathrm{Al}$ concentration with latitude during spring (a) and summer (b) and an increase in Al concentration northward in winter (c). The latitudinal trend in winter is significant at $p<0.05$. Considering all seasons together, the differences between different watershed sizes are not statistically significant $(p>0.05)$. The symbols are the same as in Fig. 2.

the full latitudinal profile, the effect of seasons was highly pronounced $(H>25, p<0.0001)$ for $\mathrm{Al}, \mathrm{Ti}, \mathrm{Mn}, \mathrm{Fe}, \mathrm{Co}$, $\mathrm{Ga}, \mathrm{Rb}, \mathrm{As}, \mathrm{Sr}, \mathrm{Mo}, \mathrm{Cd}, \mathrm{Cs}, \mathrm{Ba}, \mathrm{HREEs}, \mathrm{Hf}, \mathrm{W}$, and U. The effect was less important, although statistically significant $(8<H<30, p \geq 0.0001)$, for $\mathrm{Li}, \mathrm{B}, \mathrm{V}, \mathrm{Ni}, \mathrm{Cu}, \mathrm{Zn}, \mathrm{Sb}$, LREEs, $\mathrm{Pb}$ and $\mathrm{Th}$ and not visible for other elements.

\subsubsection{Three permafrost regions and latitudinal trends}

An assessment of the permafrost effect on TE concentration in river water is possible via distinguishing three categories of permafrost distribution in the WSL: permafrost-free, dis-

continuous and continuous permafrost zones. For these plots, we consider all seasons and river watershed sizes simultaneously. In terms of global permafrost influence, only $\mathrm{Li}$, $\mathrm{Sr}$, Mo and U showed a significant decrease (by 2 to 3 orders of magnitude) in concentrations northward (Fig. S11), consistent with statistical treatments (see below). $\mathrm{Fe}, \mathrm{Al}$ and other trivalent hydrolysates such as $\mathrm{Ga}$, Y, and REEs demonstrated an increase in concentration by more than an order of magnitude in the discontinuous and continuous permafrost zones relative to southern, permafrost-free zones (Fig. S12). This increase was most likely linked to significant increase 


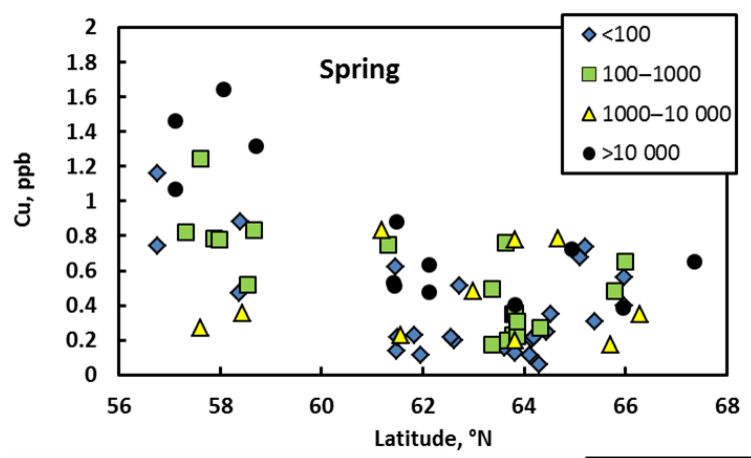

(a)
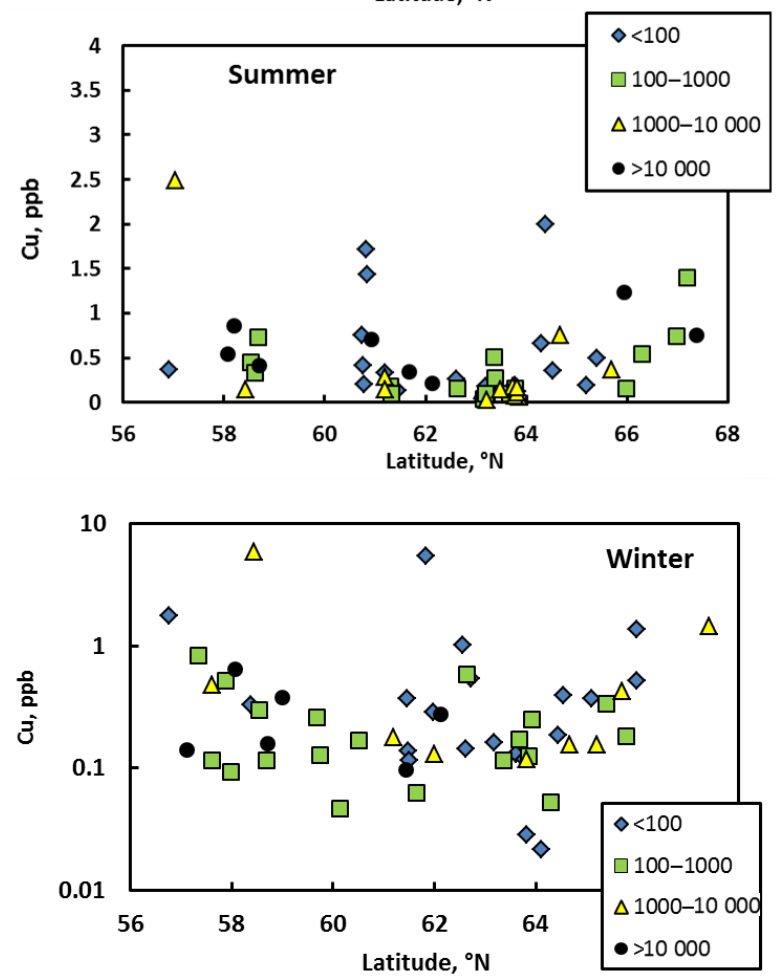

Figure 5. Variation in $\mathrm{Cu}$ concentration with latitude during spring (a), summer (b) and winter (c) for watersheds of different size. The symbols are the same as in Fig. 2.

in $\mathrm{TE}^{3+}$ concentration in winter in northern watersheds (see Sect. 3.2).

Considering all seasons simultaneously, for three permafrost zones, a statistical Kruskal-Wallis test yielded a significant impact of permafrost $(40<H<110, p<0.0001)$ for $\mathrm{Li}, \mathrm{B}, \mathrm{Ni}, \mathrm{Cu}, \mathrm{As}, \mathrm{Rb}, \mathrm{Sr}, \mathrm{Mo}, \mathrm{Sb}, \mathrm{Hf}, \mathrm{W}$ and U. To a much lesser extent $(8<H<30$, but typically from 10 to 15 at $p<0.01$ ), the permafrost impacted $\mathrm{Ti}, \mathrm{V}, \mathrm{Fe}, \mathrm{Cs}, \mathrm{Ba}$, and all REEs. All other elements, including divalent metal micronutrients $(\mathrm{Zn}, \mathrm{Mn}, \mathrm{Co})$ and pollutants $(\mathrm{Cd}, \mathrm{Pb})$, exhibited nonsignificant differences between different permafrost zones, as illustrated in Fig. S13.

The Kruskal-Wallis test of six latitudinal classes in spring yielded highly pronounced effect of latitude on $\mathrm{Li}$, V, Cr, Ni, Cu, As, Rb, Sr, Zr, Mo, Sb and U $(H>30$, $p<0.0001)$. During this period, the latitude effect was less visible for $\mathrm{Mn}, \mathrm{Fe}, \mathrm{Co}, \mathrm{Zr}, \mathrm{Nb}, \mathrm{Cs}$, REEs, Hf, W, Pb and Th $(10<H<30,0.001<p<0.05)$. In winter, six latitudinal classes were highly pronounced for $\mathrm{Ca}, \mathrm{DIC}, \mathrm{Sr}$ and $\mathrm{U}$ $(H>30, p<0.0001)$ and less visible for $\mathrm{B}, \mathrm{Al}, \mathrm{Ti}, \mathrm{Cr}, \mathrm{Mn}$, $\mathrm{Fe}, \mathrm{Co}, \mathrm{Ga}$, As, Rb, Mo, Sb, Ba, REEs, and $\mathrm{Pb}(10<H \leq 20$, $p<0.05)$. In summer, the latitudinal classes were distinct for $\mathrm{B}, \mathrm{Cu}, \mathrm{As}, \mathrm{Rb}, \mathrm{Sr}, \mathrm{Mo}, \mathrm{Ba}$ and $\mathrm{U}(H>30, p<0.0001)$, and less pronounced for $\mathrm{Be}, \mathrm{Ti}, \mathrm{V}, \mathrm{Cr}, \mathrm{Fe}, \mathrm{Ni}, \mathrm{Zr}, \mathrm{Cs}, \mathrm{REE}, \mathrm{Pb}$, $\mathrm{Hf}$, and $\mathrm{W}(10<H<30,0.001<p<0.05)$. Considering all seasons together, six latitudinal classes were strongly pronounced $(H>30, p \leq 0.0001)$ for DIC, DOC, major cations and anions, $\mathrm{Li}, \mathrm{Be}, \mathrm{B}, \mathrm{V}, \mathrm{Fe}, \mathrm{Ni}, \mathrm{Cu}, \mathrm{As}, \mathrm{Rb}, \mathrm{Sr}, \mathrm{Mo}, \mathrm{Sb}$, $\mathrm{Ba}, \mathrm{Cs}, \mathrm{Hf}, \mathrm{W}$ and $\mathrm{U}$. The impact of the latitude was significant for $\mathrm{Co}, \mathrm{Zr}, \mathrm{Nb}, \mathrm{REEs}, \mathrm{Pb}$ and $\mathrm{Th}(11<H \leq 25$, $0.0001<p<0.05)$, and not significant for $\mathrm{Al}, \mathrm{Mn}, \mathrm{Zn}, \mathrm{Ga}$ and $\mathrm{Cd}$. In agreement with the trends shown in Figs. 8-10, the latitude effect is most strongly pronounced for $\mathrm{Sr}, \mathrm{Mo}$, and $\mathrm{U}(H=122,110$, and 123 , respectively).

\subsection{TE fluxes in western Siberian rivers across the permafrost gradient}

TE fluxes were computed based on mean multi-annual monthly average discharge of sampled rivers and measured concentrations during three main hydrological seasons (spring flood, summer and winter baseflow including October), normalized to the watershed area at the point of river sampling. Considering the high variability in concentrations among individual rivers during a given season, the typical uncertainties of the average of several rivers in each latitudinal class $\left(56-58,58-60,60-62,62-64,64-66\right.$ and $\left.66-68^{\circ} \mathrm{N}\right)$ are between 20 and $30 \%$. Note that TE flux calculation may be biased by an insufficient number of observations over the year, namely during long winter baseflow, and one single measurement during the hydrologically important spring flood period. As such, the overall uncertainty of the annual fluxes of TEs in each latitudinal range ranged between \pm 20 and $\pm 50 \%$ of the mean value. This uncertainty was calculated as the sum of uncertainties of each season. The uncertainty of each season flux was proportional to the contribution of this season to the annual flux. We consider this to be a reasonable evaluation given the large variations in chemical composition of small rivers over the year. In addition, having a significant number of rivers in each latitudinal class, integrating all sizes of the watersheds, greatly enforces the validity of our flux calculations.

Taking into account the abovementioned uncertainties, most TEs did not demonstrate a statistically significant (at $p<0.05)$ latitudinal trend of export fluxes, which was the case for some typical hydrolysates (Al, Ti, La, Zr, Th), oxyanions (B, As, Sb), and metals (Cr, Mn, Co, Ba, Rb, Cu, $\mathrm{Pb}$ ). At the same time, many elements ( $, \mathrm{Cr}, \mathrm{Mn}, \mathrm{Cu}, \mathrm{Co}$, $\mathrm{Ni}$, As, Zr, REEs, Th) demonstrated an elevated flux in the northernmost latitudinal range, without a clear trend in rivers 

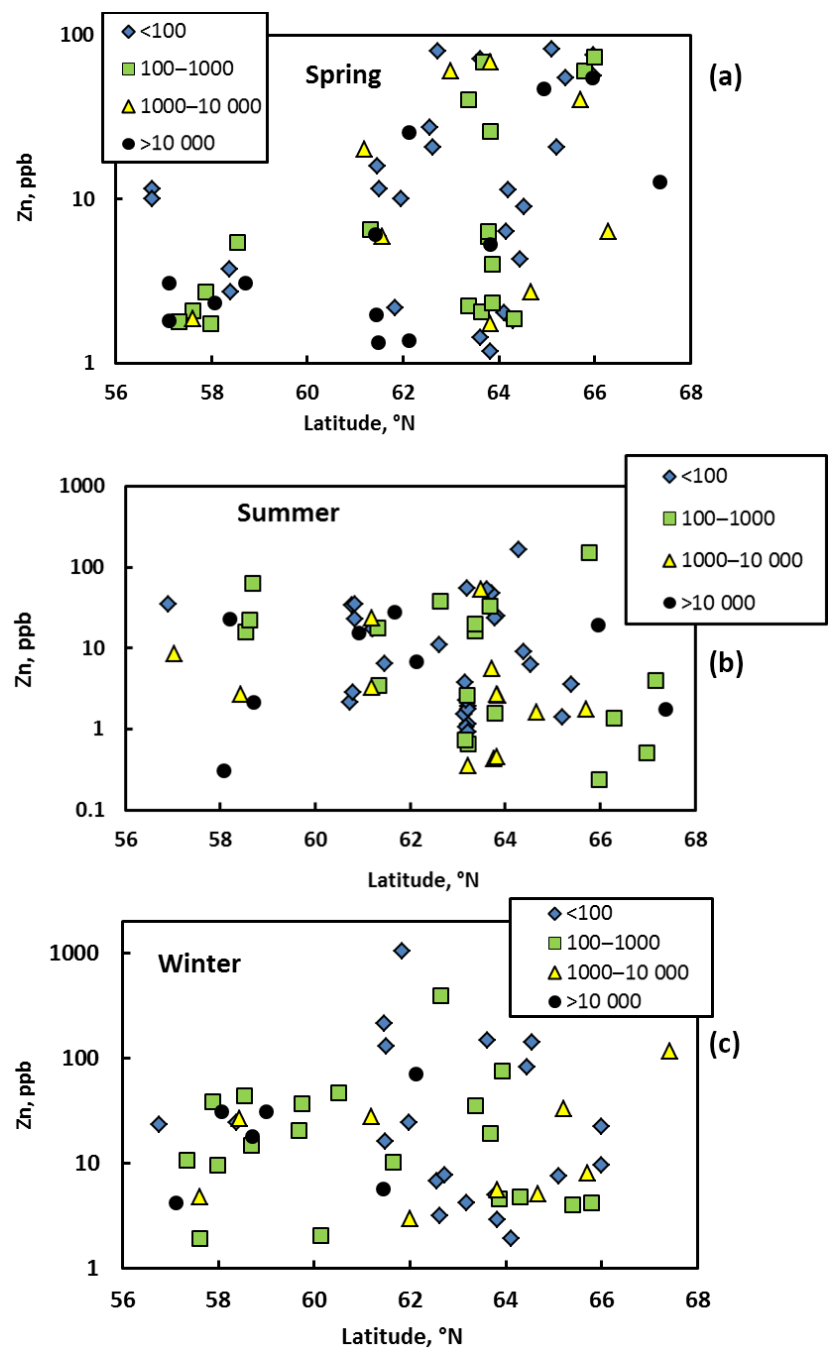

Figure 6. Variation in $\mathrm{Zn}$ concentration with latitude during spring (a), summer (b) and winter (c) for watersheds of different size. The symbols are the same as in Fig. 2.

south of $66^{\circ} \mathrm{N}$. This single latitude range was not considered significant as it marked the elevated concentration of elements in only one river in winter and four rivers in summer and thus could be biased by the low number of sampled rivers. Because all rivers north of $66^{\circ} \mathrm{N}$ except the largest, Khadutte $\left(67.41^{\circ} \mathrm{N}, 4933 \mathrm{~km}^{2}\right)$, were completely frozen, the river fluxes in winter in this latitudinal range can be considered to be zero. Neglecting wintertime fluxes in the latitudinal range $66-68^{\circ} \mathrm{N}$ removed anomalously high annual values for $\mathrm{Cr}, \mathrm{Mn}, \mathrm{Fe}, \mathrm{Cu}, \mathrm{Zn}, \mathrm{Co}$, As, Rb, Zr, REEs, Cd and Th, rendering the northernmost fluxes of continuous permafrost zone for these elements similar to those of permafrostfree and discontinuous permafrost regions without statistically significant $(p>0.05)$ trend across the $1500 \mathrm{~km}$ latitudinal transect. $\mathrm{Fe}, \mathrm{Zn}$, and $\mathrm{Cd}$ demonstrated a clear increase $(p<0.05)$ in fluxes northward (Fig. S14). This increase was
Table 2. Latitude-averaged $\left(56-67^{\circ} \mathrm{N}\right)$ export fluxes $( \pm 2 \mathrm{SD})$ of TEs by rivers of the WSL.

\begin{tabular}{lll}
\hline Element & Flux, $\mathrm{kg} \mathrm{km}^{-2} \mathrm{yr}^{-1}$ & Flux, $\mathrm{kg} \mathrm{km}^{-2} \mathrm{yr}^{-1}$ \\
\hline $\mathrm{B}$ & $4.3 \pm 1.9$ & $4.1 \pm 1.8$ \\
$\mathrm{Al}$ & $8.5 \pm 2.2$ & $8.1 \pm 2.3$ \\
$\mathrm{Ti}$ & $0.20 \pm 0.06$ & $0.19 \pm 0.06$ \\
$\mathrm{~V}$ & $0.12 \pm 0.07$ & $0.12 \pm 0.05$ \\
$\mathrm{Cr}$ & $0.083 \pm 0.022$ & $0.077 \pm 0.014$ \\
$\mathrm{Mn}$ & $49.2 \pm 30.0$ & $33.8 \pm 8.7$ \\
$\mathrm{Fe}$ & $211 \pm 124$ & $165 \pm 84$ \\
$\mathrm{Cu}$ & $0.12 \pm 0.07$ & $0.108 \pm 0.046$ \\
$\mathrm{Zn}$ & $4.2 \pm 2.6$ & $3.2 \pm 1.7$ \\
$\mathrm{Co}$ & $0.17 \pm 0.24$ & $0.074 \pm 0.029$ \\
$\mathrm{Ni}$ & $0.26 \pm 0.17$ & $0.23 \pm 0.10$ \\
$\mathrm{Rb}$ & $0.14 \pm 0.06$ & $0.12 \pm 0.05$ \\
$\mathrm{Sr}$ & $26-3.6^{2}$ & $14.0 \pm 9.8$ \\
$\mathrm{Zr}$ & $0.033 \pm 0.014$ & $0.030 \pm 0.009$ \\
$\mathrm{Mo}$ & $0.034-0.0025^{2}$ & $0.012 \pm 0.012$ \\
$\mathrm{Cd}$ & $0.0028 \pm 0.0012$ & $0.0023 \pm 0.0009$ \\
$\mathrm{Sb}$ & $0.0067 \pm 0.0017$ & $0.0062 \pm 0.0014$ \\
$\mathrm{As}$ & $0.19 \pm 0.12$ & $0.173 \pm 0.097$ \\
$\mathrm{Ba}$ & $10.2 \pm 5.2$ & $9.2 \pm 5.6$ \\
$\mathrm{La}$ & $0.025 \pm 0.014$ & $0.020 \pm 0.004$ \\
$\mathrm{Ce}$ & $0.055 \pm 0.031$ & $0.044 \pm 0.008$ \\
$\mathrm{Nd}$ & $0.029 \pm 0.017$ & $0.024 \pm 0.006$ \\
$\mathrm{~Pb}$ & $0.033 \pm 0.012$ & $0.032 \pm 0.014$ \\
$\mathrm{Th}$ & $0.0036 \pm 0.0014$ & $0.0031 \pm 0.0009$ \\
$\mathrm{U}^{2}$ & $0.017-0.0011^{2}$ & $0.0057 \pm 0.0062$ \\
\hline
\end{tabular}

${ }^{1} 56-66^{\circ} \mathrm{N}$, neglecting the Khadutte River in winter. ${ }^{2}$ Average value cannot be given.

more significant (at $p<0.05$ ) than the individual uncertainties in each latitudinal range.

The TE annual fluxes in WSL rivers can be averaged over the full latitudinal range and are listed in Table 2. A few elements (Sr, Mo, U) yielded a distinct decrease in annual fluxes northward, with some re-increase in the continuous permafrost zone, persisting even after removal of anomalously high wintertime concentrations of the Khadutte River (Table 2, Fig. S15). For these elements, no definite value of WSL river flux could be given.

\subsection{TE speciation in western Siberian rivers}

Element speciation in the dissolved $(<0.45 \mu \mathrm{m})$ phase calculated using Stockholm Humic Model (vMinteq) is illustrated as a stack diagram in Fig. 11. This calculation was performed based on seasonally averaged concentrations of major and trace elements in three distinct geographical zones of the WSL: permafrost-free, discontinuous and continuous permafrost. Trivalent hydrolysates, including $\mathrm{Fe}, \mathrm{Pb}^{2+}$ and $\mathrm{Cu}^{2+}$, were present as $>90 \%$ organic complexes, regardless of the type of permafrost abundance. Alkaline earth metals and $\mathrm{Mn}^{2+}$ were essentially in the form of free ions 

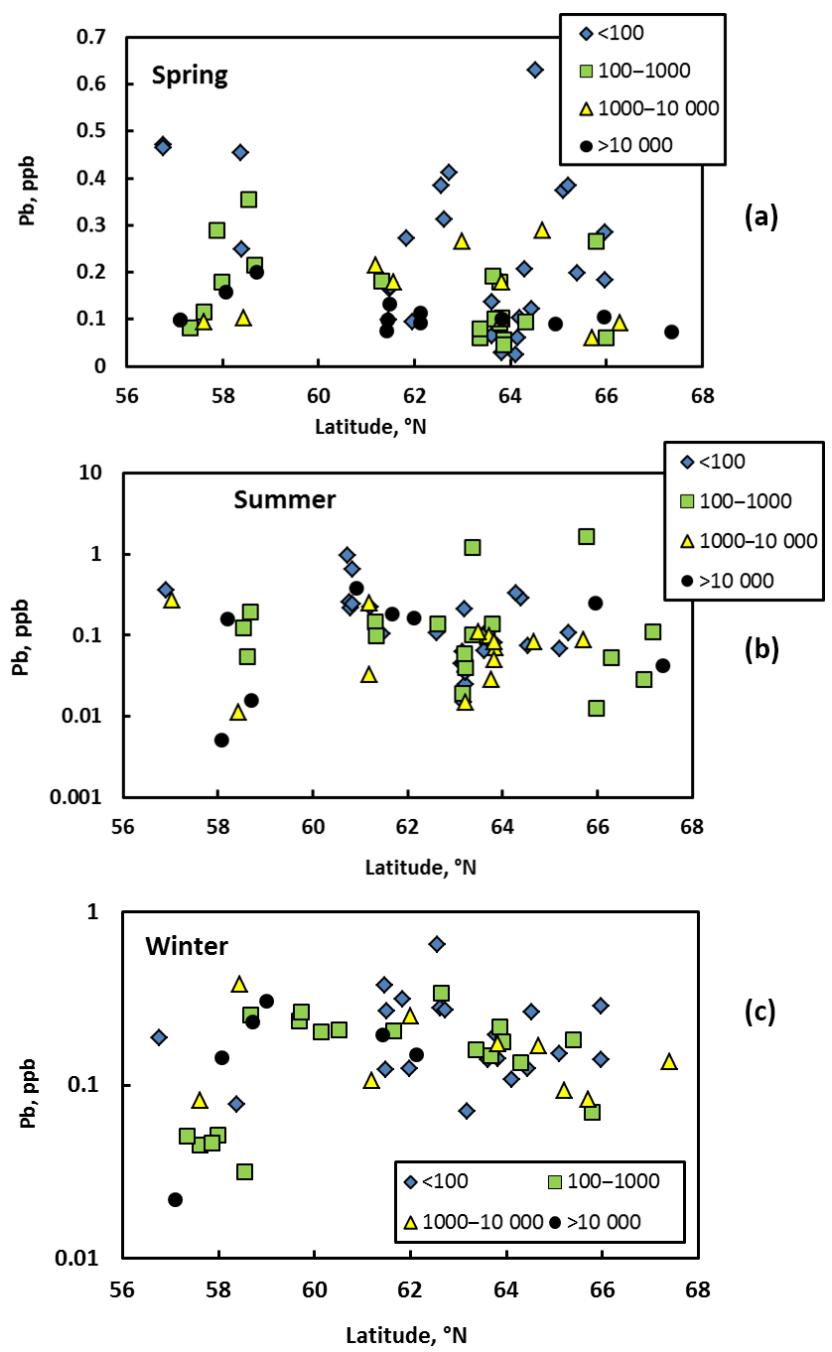

Figure 7. The variation of $\mathrm{Pb}$ concentration with latitude during spring (a), summer (b) and winter (c) for watersheds of different size. The symbols are the same as in Fig. 2.

with $<15 \%$ of organic complexes. Transition metals exhibited a variable proportion of organic complexes (from 20 to $60 \%$ ), without any trend related to the type of permafrost abundance. Considering all divalent metals, the following order of organic complexation was observed: Co $<\mathrm{Cd} \sim \mathrm{Zn}<\mathrm{Ni} \ll \mathrm{Pb}<\mathrm{Cu}$. Uranium exhibited the most contrasting speciation between permafrost-free, DIC-rich rivers (from 10 to $70 \%$ of organic complexes) and permafrostbearing zones $(>90 \%)$. This contrast was linked to elevated concentrations of $\mathrm{HCO}_{3}^{-}$ions in southern rivers, where inorganic $\mathrm{U}(\mathrm{VI})$-carbonate species were prevailing.
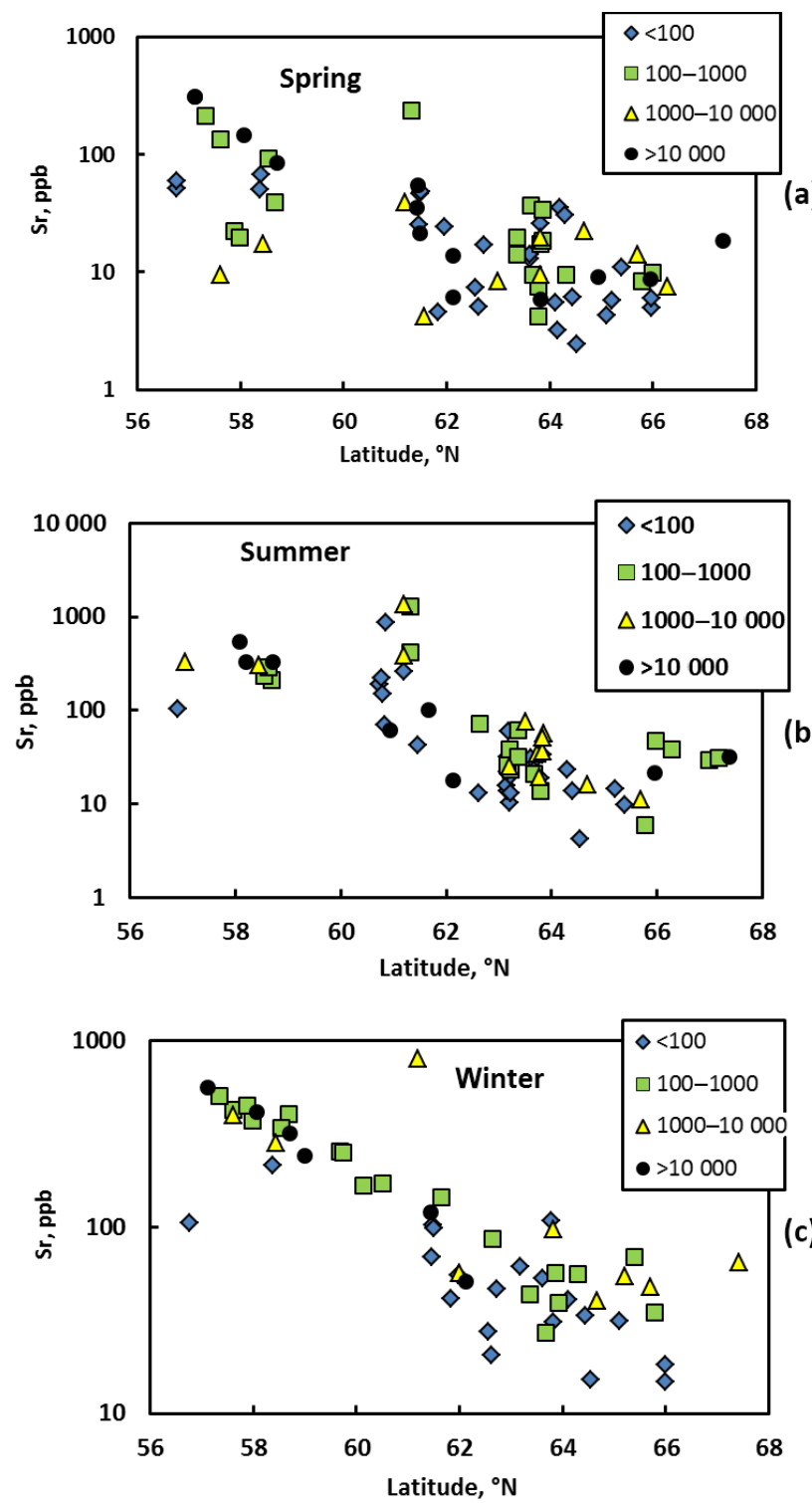

Figure 8. Variation in $\mathrm{Sr}$ concentration with latitude during spring (a), summer (b) and winter (c) for watersheds of different size. The symbols are the same as in Fig. 2. A clear groundwater effect consists in a gradual decrease in concentration northwards, most visible during winter baseflow.

\section{Discussion}

\subsection{General features of TE migration across the permafrost gradient and TE correlations with DOC, DIC, Fe and $\mathrm{Al}$ and landscape components}

From general knowledge of environmental control on TE fluxes in rivers of the Russian and Siberian subarctic (Pokrovsky et al., 2006, 2012) and other boreal and subartic regions (Huh et al., 1998; Millot et al., 2003; Rember and Trefry, 2004; Huser et al., 2011), the evolution of element 

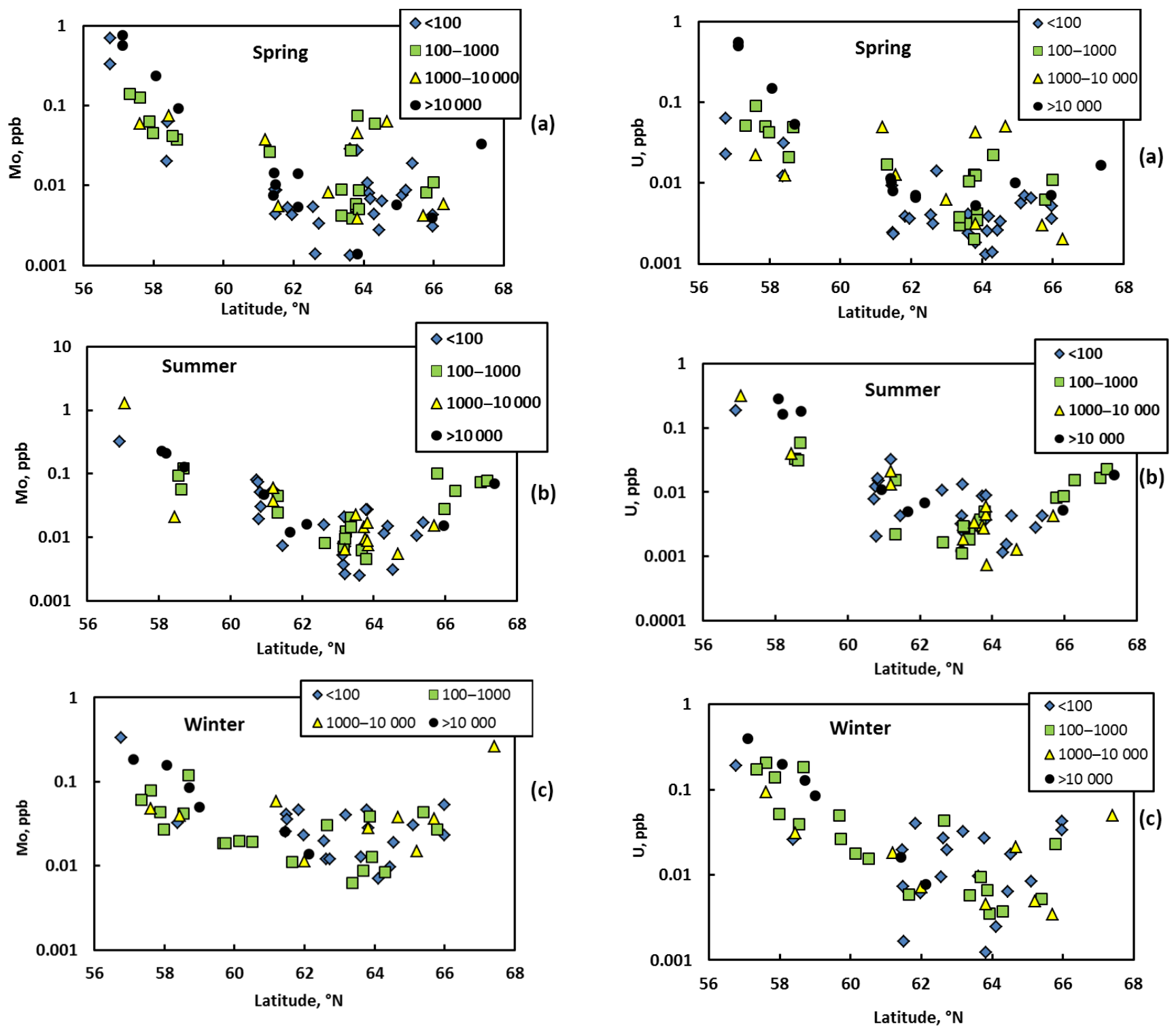

Figure 9. Variation in Mo concentration with latitude during spring (a), summer (b) and winter (c) for watersheds of different size. The symbols are the same as in Fig. 2. A clear groundwater effect consists in a gradual decrease in concentration northwards, most visible during winter baseflow.

concentration over the latitudinal profile of variable permafrost coverage and vegetation at otherwise similar bedrock lithology and physico-geographical settings is governed by several counterbalanced processes. A decrease in mobile element (alkali and alkaline earth elements, oxyanions) concentration northward in the WSL may be due to (1) a decrease in chemical weathering intensity with the temperature (Oliva et al., 2003; Beaulieu et al., 2012), (2) a decrease in the thickness of the active (unfrozen) soil layer (Beilman et al., 2009), and (3) a decrease in the degree of groundwater feeding (Frey et al., 2007b). These factors will mostly act on

elements whose transport is not limited by dissolved organic matter. The size of a river is expected to act essentially on the third factor, via decreasing the degree of river feeding by underground taliks with the decrease in the watershed area: it is fairly well known that the larger the river, the stronger the impact of underground input, notably in the permafrost zone of western Siberia (Fotiev, 1989, 1991).

The factors capable of enhancing element concentration and export flux in northern (permafrost-bearing) rivers relative to southern (permafrost-free) rivers are those controlling the export of DOM and related metal complexes: (1) the 
increase in DOC and related element leaching from plant litter and topsoil (Pokrovsky et al., 2012; Giesler et al., 2006; Fraysse et al., 2010) during a more pronounced massive freshet event or summer high flow (Michel and Vaneverdingen, 1994; Rember and Trefry, 2004; McClelland et al., 2006; White et al., 2007); (2) enhanced mobility of lowsolubility TEs during the spring acid pulse (well established in other permafrost-free boreal regions; Buffam et al., 2007), which is pronounced only in permafrost-affected rivers of western Siberia (Pokrovsky et al., 2015); and (3) the decrease in adsorption of DOM-metal complexes on the mineral soil horizon because the clay horizon is typically frozen in the north (Kawahigashi et al., 2004). These enhancing factors are tightly linked to the nature of colloidal carriers of TEs (organic, organo-ferric or organo-aluminum species) and the efficiency of metal leaching from the organic topsoil and plant litter. A comprehensive database of rivers of various sizes across the full gradient of permafrost investigated during the main hydrological seasons in this study allows testing of the abovementioned environmental factors.

DOC and $\mathrm{Fe}$ are not correlated in rivers $(R<0.40$; $p>0.05$ ), and this is consistent with decoupling of $\mathrm{Fe}$ and DOC during the size separation procedure as two independent colloidal pools, already demonstrated for European boreal rivers (Lyvén et al., 2003; Neubauer et al., 2013; Vasyukova et al., 2010) and other Siberian rivers and WSL thermokarst lakes (Pokrovsky et al., 2006, 2011). The highest correlation coefficients between DOC and divalent metals and hydrolysates observed in summer may indicate the importance of DOM in these elements' mobilization from the vegetation pool or from soil mineral horizons. The latter pool is poorly pronounced in spring. Significant correlation of $\mathrm{Al}$ with insoluble low-mobility elements such as $\mathrm{Be}, \mathrm{Ti}$, $\mathrm{Cr}, \mathrm{Ga}, \mathrm{Zr}, \mathrm{Cd}$, REEs, Hf and Th was mostly pronounced during the open-water period. A likely cause of this coupled transport is the concomitant release of these elements from soil peat or the mineral horizon. Most likely, organo-Al colloids, also highly abundant in western Siberian thermokarst lakes (Pokrovsky et al., 2011), act as carriers of insoluble hydrolysates from the organic or mineral (clay) soil constituents to the river. A decoupling of total dissolved Fe concentration from these correlations during all seasons is due to Fe vulnerability to redox processes. As a result, although organo-ferric colloids may still be important carriers of TEs, a significant fraction of dissolved $\mathrm{Fe}$ in Fe-rich streams, especially in winter, can be in $\mathrm{Fe}$ (II) form. Reductive dissolution of iron and manganese oxy(hydr)oxides in temperate soils is known to promote the release of $\mathrm{Ba}, \mathrm{Cd}, \mathrm{Cu}, \mathrm{Co}, \mathrm{Cr}$, $\mathrm{Ni}$ and V (Abgottspon et al., 2015; Hindersmann and Mansfeldt, 2014; Weber et al., 2009). Underground water influx can be an additional source of some low-mobility metals, reflected in Fe and Mn concentrations that are 1-2 orders of magnitude higher in winter (Figs. $2 \mathrm{c}$ and $4 \mathrm{c}$ ) and in statistically significant correlation coefficient with $\mathrm{Fe}$ of $\mathrm{Ti}, \mathrm{V}, \mathrm{Cr}$, $\mathrm{Mn}, \mathrm{Ga}$, As, and Zr (Table S1, Sect. 3.1).

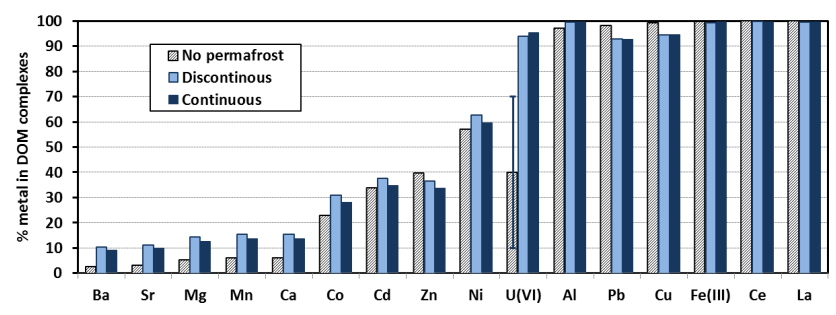

Figure 11. Percentage of organic complexes in western Siberian rivers $(<0.45 \mu \mathrm{m}$ fraction) calculated using the Stockholm Humic Model (vMinteq, version 3.1; Gustafsson, 2014). Values of major and trace elements measured in 66 rivers in the permafrost-free zone, 110 rivers in the discontinuous permafrost zone and 39 rivers in the continuous permafrost zone averaged over all seasons were used.

Although the impact of main landscape components of the river watershed (bogs, lakes and forest) is statistically significant at $p<0.05$, the correlation coefficients are rather low (typically from \pm 0.30 to \pm 0.45 ; see Table S2). Nevertheless, analysis of the correlation matrix revealed that lakes remove $\mathrm{Mn}, \mathrm{Co}$ and $\mathrm{Si}$ in summer and $\mathrm{Ni}, \mathrm{Cu}$ and $\mathrm{Rb}$ in spring, which can be related to both phototrophic $\left(\mathrm{Mn}^{2+}\right.$ oxidation) and biotic (uptake of plankton, periphyton and macrophytes) mechanisms. The enrichment of rivers with a high lake proportion at the watershed in insoluble elements such as $\mathrm{Al}, \mathrm{Cu}, \mathrm{Cd}$, REEs and $\mathrm{Pb}$ in summer and in trivalent and tetravalent hydrolysates in winter may be linked to TE mobilization from lake sediments. Unlike the major part of the peat soil profile, the clays and sand sediments of lakes may remain unfrozen (i.e., Manasypov et al., 2015), thus releasing these lithogenic elements. Note that bogs enriched the rivers in insoluble elements mainly in winter, which can be due to enhanced mobilization of $\mathrm{TE}^{3+}$ and $\mathrm{TE}^{4+}$ in the form of organic-rich colloids.

The PCA results revealed two possible factors controlling element distribution in rivers during all seasons, across the latitudinal and permafrost gradient: F1 is presumably linked to organic and organo-mineral colloids, acting on insoluble, low-mobility element hydrolysates (Be, Al, Ti, Zr, Nb, REEs, $\mathrm{Hf}, \mathrm{Th}$ ) and associated with the presence of forest on the watershed and F2 being directly linked to the negative latitude, which controls S.C., DIC, Ca, Mg, K, Li, V, As, Rb, Sr, Mo, $\mathrm{Sb}, \mathrm{W}$ and $\mathrm{U}$, whose concentrations greatly decrease northward during all seasons (see Fig. S1a and b). The importance of this factor increases with the decrease in the proportion of lakes and bogs on the watershed because wetlands are known to limit element export in the boreal zone (Lidman et al., 2011, 2014).

The lack of a watershed area and discharge effect on F1 $\times$ F2 structure revealed during PCA treatment suggests that the size of a watershed does not control element concentration in rivers across the permafrost gradient during various seasons (see results of Kruskal-Wallis test in Sect. 3.3.1). An 
important result is the persistence of $\mathrm{F} 1 \times \mathrm{F} 2$ factorial structure with relatively similar eigenvalues over all four hydrological seasons, including winter baseflow. This suggests the dominance of two main processes controlling element mobilization from the soil to the river: organo-colloidal DOC-rich surface flow and deep underground or subsurface feeding by DIC-rich, DOC-poor waters, as also evidenced in analyses of major cations $(\mathrm{Ca}, \mathrm{Mg}$ ) of the WSL rivers (Pokrovsky et al., 2015).

Despite the significant latitudinal and geographical coverage of western Siberian rivers, PCA does not allow for an explanation of the observed variability in solute composition in western Siberia due to its highly homogeneous environmental context (Pokrovsky et al., 2015), unlike that of the Mackenzie River drainage basin (Reeder et al., 1972). In the latter, however, contrasting lithological and physicogeographical factors (carbonate, gypsum, clays, halite deposits, hot springs) create a distinct component structure. Another reason for the relatively low efficiency of PCA in explaining TE concentration variability (only 33\%) is that a fair number of TEs, such as divalent metals (Mn, Zn, Bi, Co, $\mathrm{Cu}, \mathrm{Cd}, \mathrm{Pb}$ ), are linked to neither latitude (groundwater feeding) nor $\mathrm{Al} / \mathrm{Fe}$-rich organic colloids. As a result, not all of the variables respond to the observed PCA F1 $\times$ F2 structure.

\subsection{Effect of latitude on TE concentration and export from the soil profile and groundwater to the river}

The decrease in concentration of elements originating from water-rock interaction whose transport is not limited by the availability of DOM (Ca, Mg, DIC, Li, B, V, Cr, Sr, Rb, $\mathrm{As}, \mathrm{Sb}, \mathrm{Mo}, \mathrm{U})$ is expected to be directly related to the concentration of these elements in underground waters contacting basement rocks. In winter, when the contribution of the groundwater relative to the surface runoff is maximal (i.e., Walvoord et al., 2012; Walvoord and Striegl, 2007), one can the expect most significant effect of the latitude on these element concentration to be in rivers. In addition, in the permafrost-bearing zone during winter baseflow, significant difference in element concentration in winter between small rivers (not affected or weakly affected by taliks) and large rivers (essentially fed by taliks) should occur. In contrast, in spring, when the majority of the soil column is frozen, the export from the watershed is dominated by surface flux over the frozen organic horizon and thus the difference in groundwater-related element concentration between small and large rivers or between north and south should be minimal. The groundwater feeding of WSL rivers ranges significantly from the southern permafrost-free zone $\left(56\right.$ to $\left.58^{\circ} \mathrm{N}\right)$, where it varies between 30 and $80 \%$ (Frey et al., 2007b), to $20-30 \%$ in the discontinuous and sporadic/isolated part of the WSL and decreases down to 3-6\% in the northern, continuous permafrost zone (Novikov et al., 2009). This decrease in groundwater feeding is capable of partially explaining an order of magnitude decrease in $\mathrm{Sr}$, Mo and $\mathrm{U}$ across the studied gradient (Figs. 8-10 and S11). However, the latitudinal trend of soluble TE ( $\mathrm{Sr}, \mathrm{Mo}, \mathrm{As}, \mathrm{Sb}$, and $\mathrm{U}$ ) concentration reaches 2 orders of magnitude and persists regardless of the season and the watershed size, thus implying more than one single source of soluble elements in the rivers.

Therefore, we hypothesize that, in addition to deep underground feeding, there is element leaching from the main constituents of the soil profile - peat and mineral horizons. This leaching essentially controls the gradual decrease in soluble element concentration in rivers northward, visible during all seasons. The capacity of soil substrate to release TEs to the river can be evaluated based on available elemental composition of WSL peat (Stepanova et al., 2015). At present, this is the only source of information on TE concentration in moss cover, peat and mineral horizons of WSL soils over a latitudinal transect of more than $1500 \mathrm{~km}$ that is similar to that investigated in the present work. Among 50 major and trace elements analyzed in the main soil reservoirs of the WSL, only a few TEs demonstrated a statistically significant $(p<0.05)$ latitudinal concentration trend. For example, an order of magnitude decrease in $\mathrm{Sr}$, Mo, and $\mathrm{U}$ northward in peat and mosses of the WSL between 55 and $66^{\circ} \mathrm{N}$ (Fig. S16) may reflect the latitudinal evolution of the lithological substrate background across the WSL. Tentatively, it corresponds to a decrease in the content of carbonate concretions in the clayey horizons. The decrease in $\mathrm{Sr}$, Mo and $\mathrm{U}$ concentration northward is detectable in all four main compartments feeding the river: (1) soluble products of rock weathering in the underground reservoirs, (2) deep soil/subsurface fluids interacting with the mineral part of the soil profile, (3) interstitial soil solutions of the peat horizons, and (4) plant litter/moss layer leachates transported to the river via surface runoff in the permafrost-free zone and suprapermafrost flow in the permafrost-bearing zone.

An additional factor of enhanced $\mathrm{Sr}$, Mo and $\mathrm{U}$ mobility in the southern rivers relative to northern rivers is the difference of the $\mathrm{pH}$ regime between permafrost-free and permafrostbearing zones of the WSL. The $\mathrm{pH}$ values of 7 to 7.5 in the southern rivers observed both in winter and spring are indicative of carbonate/silicate rock weathering in the underground reservoirs. The spring acid pulse, reported for other permafrost-free boreal regions (Buffam et al., 2007), is not pronounced in the south of the WSL but becomes clearly visible in the permafrost-affected northern regions where the springtime $\mathrm{pH}$ decreases to $5.5 \pm 0.5$ (Pokrovsky et al., 2015). Decreased mobility of Mo and other oxyanions in more acidic solutions may be directly linked to their adsorption on mineral and organic surfaces, whereas enhanced $U$ concentrations in DIC-rich, circumneutral solutions may be due to strong carbonate and hydroxycarbonate complexes replacing organic colloids (Fig. 11), as is also known for European subarctic rivers (Porcelli et al., 1997; Pokrovsky et al., 2010). Finally, high sensitivity of Sr to the latitudinal trend is likely to reflect its co-mobilization together with $\mathrm{Ca}$ and DIC from both surface and subsurface sources. 
A wintertime increase in Fe concentration in permafrostaffected rivers relative to the permafrost-free region (Fig. 2c) may reflect enhanced $\mathrm{Fe}(\mathrm{II})$ mobilization from anoxic underground reservoirs and iron oxy(hydr)oxide dissolution in river sediments. This input is visible mostly during winter, when thick ice cover created partially anoxic conditions suitable for $\mathrm{Fe}(\mathrm{II})$ maintenance in solution. These conditions were most pronounced in northern, permafrost-affected regions, where the ice thickness was higher and some rivers even froze solid in February. At the same time, the lack of Mn increase northward in winter (Fig. 4c) suggests relatively weak control of solely anoxic conditions on metal transport. Alternatively, these anoxic conditions suitable for enhanced Mn mobilization remain similar across the latitudinal profile, as Mn concentration remains quasi-constant and systematically higher ( 1 to 2 orders of magnitude) in all rivers in winter relative to spring and summer (Fig. 4). Note that enhanced Mn transport during the winter period linked to its redox-driven mobilization from lake and river sediments is fairly well established for small Scandinavian rivers (Pontér et al., 1990, 1992). Concerning trivalent and tetravalent hydrolysates, we hypothesize mobilization of $\mathrm{TE}^{3+}$ and $\mathrm{TE}^{4+}$ by $\mathrm{Fe}(\mathrm{III})$ colloids in the river water. These colloids are produced in the hyporheic zone of the river, fed by taliks from underground reservoirs. Very strong association of these elements with Fe(III) colloids stabilized by DOM is fairly well established in WSL thermokarst lakes and small rivers of the discontinuous permafrost zone (Pokrovsky et al., 2011; Shirokova et al., 2013). A positive correlation between $\mathrm{Fe}$ and other hydrolysates and the proportion of lakes and bogs at the watershed (Table S2) also confirms the importance of wetlands in providing organic carriers for these low-mobile elements.

An increase in element concentration in rivers north of $66^{\circ} \mathrm{N}$ compared to the permafrost-free zone, especially visible for $\mathrm{B}, \mathrm{V}, \mathrm{Ni}, \mathrm{Rb}, \mathrm{Sr}, \mathrm{Mo}$, As and $\mathrm{U}$ during summertime (Figs. 8b, 9b, 10b, S4, S8 and S9), does not have a straightforward explanation. We can hypothesize the influence of marine sediments underlying frozen peat in the 50$100 \mathrm{~km}$ vicinity of the shoreline (see Sect. 4.3 below for soil profile). In addition, the ground vegetation may be enriched in seawater aerosols transported from unfrozen coastal waters in the form of rain and fog. An increase in B, Sr, Mo, $\mathrm{Rb}$ and $\mathrm{U}$ as well as $\mathrm{Na}, \mathrm{Mg}, \mathrm{K}$ and $\mathrm{Ca}$ of marine origin in large thermokarst lakes north of $68^{\circ} \mathrm{N}$ relative to discontinuous permafrost zone was reported for the northern part of the WSL (Manasypov et al., 2014).

Despite contrasting hydrochemistry of WSL rivers in permafrost-free, discontinuous and continuous permafrost regions in terms of $\mathrm{pH}$ and DOC concentration (Frey and Smith, 2005; Pokrovsky et al., 2015), the percentage of organic complexes of TEs remained quite similar among all three permafrost zones. Among metals available in the vMinteq database, $\mathrm{Mg}, \mathrm{Ca}, \mathrm{Sr}, \mathrm{Ba}$, and $\mathrm{Mn}$ are complexed to $\mathrm{DOM}$ at 5 to $15 \%$; $\mathrm{Co}, \mathrm{Cd}$ and $\mathrm{Zn}$ are complexed from 20 to
$40 \%$; $\mathrm{Ni}$ is complexed at 55-60\%; and $\mathrm{Al}, \mathrm{Pb}, \mathrm{Cu}, \mathrm{Fe}(\mathrm{III})$, $\mathrm{La}, \mathrm{Ce}$ and other REEs are bound to DOM by 90 to $98 \%$ (Fig. 12). Only U(VI) exhibited contrasting speciation between permafrost-free and permafrost-bearing zones. From 10 to $70 \%$ of $\mathrm{U}$ is present as organic complexes in $\mathrm{HCO}_{3}^{-}$rich, circumneutral solutions of southern rivers but U(VI) remained $>90 \%$ DOM-complexed in acidic, DIC-poor northern rivers.

The annual TE fluxes of WSL rivers averaged over the full latitudinal profile (Table 2) can be compared with available data of TE fluxes in other subarctic rivers. Such a comparison is possible for the Severnaya Dvina River, the largest European subarctic river, whose watershed lies on the same latitudinal range $\left(58-64^{\circ} \mathrm{N}\right)$ as most WSL rivers but in the permafrost-free zone (Pokrovsky et al., 2010). The ratio of annual element fluxes in the Severnaya Dvina River measured in 2007-2009 to mean fluxes of the WSL rivers is plotted in Fig. S17. Given that the uncertainties on the flux evaluation in each region range between \pm 30 and $\pm 50 \%$, the agreement within a factor of 1.5 to 2 is within the uncertainty. The elevated flux of $\mathrm{Sr}$ and $\mathrm{U}$ in the Severnaya Dvina River relative to the WSL rivers is due to the presence of carbonate rocks, whereas the elevated fluxes of lithogenic elements ( $\mathrm{Zr}$, Th, REEs, Al, Ti) are due to silicate rock (granites and their moraine) on the watershed of Severnaya Dvina (see Pokrovsky et al., 2010, for lithological description). The reasons for fluxes of $\mathrm{Ni}, \mathrm{Cu}$, and $\mathrm{Cd}$ being more than an order of magnitude higher in the Severnaya Dvina River relative to the WSL rivers are multiple and may include (i) the presence of sedimentary sulfides in the former, (ii) enhanced uptake of these metals by peat mosses in the WSL and finally (iii) anthropogenic local pollution by these metals in the Severnaya Dvina River.

\subsection{Mechanisms of TE mobilization from the soil to the river}

Together with a comprehensive database of concentration, colloidal status and fluxes of TEs in the Kalix River (i.e., Ingri et al., 2000, 2005; Andersson et al., 2001; Dahlqvist et al., 2007), the Kryckland watershed (Björkvald et al., 2008; Laudon et al., 2013), and Alaskan rivers (Sugai and Burrell, 1984; Rember and Trefry, 2004), the present study contributes to our understanding of the nature and magnitude of element transport in boreal rivers. The main peculiarity of the WSL region is the presence of permafrost in almost half of its area. This permafrost likely acts as a very strong barrier between surface organic and underlying mineral soil horizon, thus regulating the degree of mineral vs. peat leaching depending on latitude and season, as is known for other subarctic environments (Bagard et al., 2011, 2013; Keller et al., 2007, 2010).

A tentative scheme of WSL soil profiles in the permafrostfree, discontinuous and continuous permafrost zone presenting TE mobilization pathways from the soil to the river is il- 
(a) Forest watershed, $57^{\circ} \mathrm{N}$, August Dark coniferous taiga

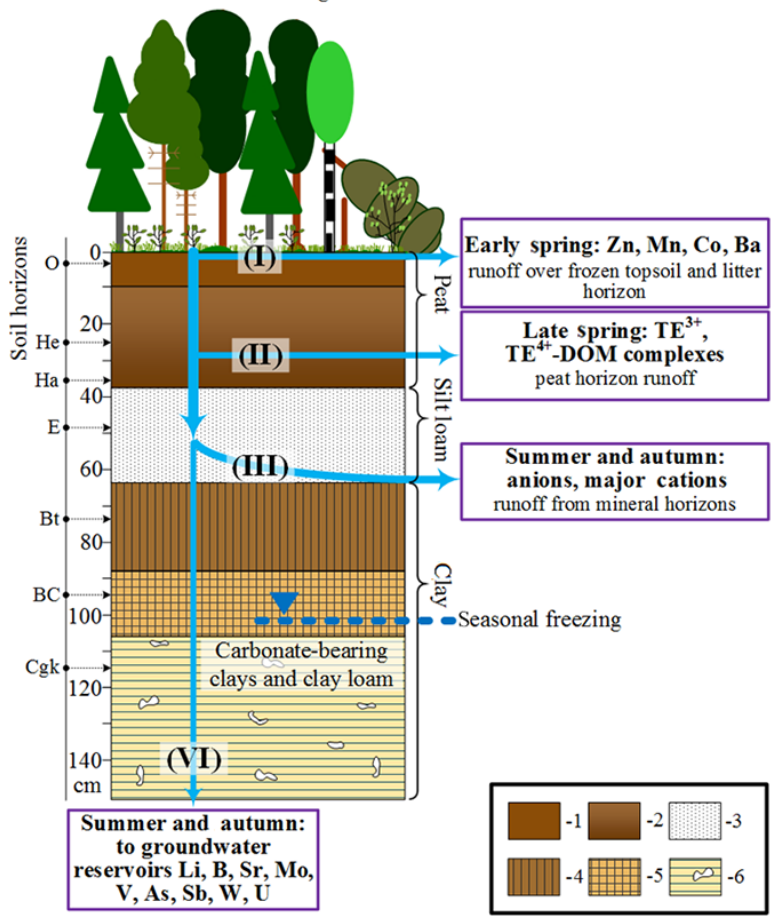

\section{(b) Discontinuous permafrost}

Frozen bog watershed $67^{\circ} \mathrm{N}$, August

Waterlogged rarefied pine forest

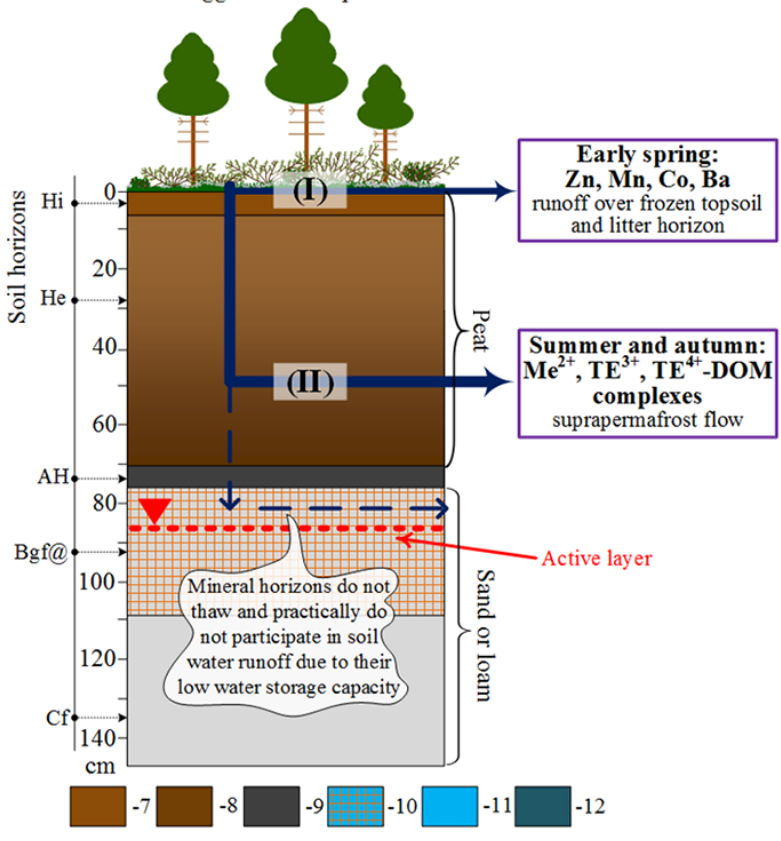

(c) Frozen bog watershed $67^{\circ} \mathrm{N}$, August Continuous permafrost

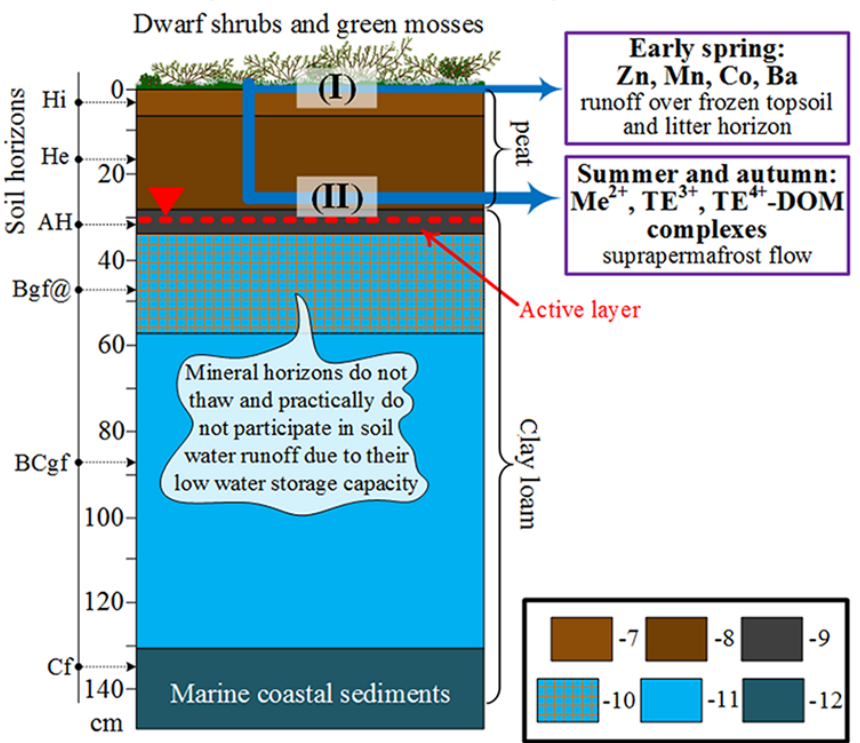

Figure 12. Scheme of TE pathways within the soil profile and to the river. (a) In a forest watershed of the south, permafrost-free zone $\left(57^{\circ} \mathrm{N}\right)$ and (b) a discontinuous permafrost forest-tundra zone. Soil horizons (FAO, 2006): 1, O (Mor, forest litter); 2, medium-decomposed peat $(\mathrm{He})$ transforming into strongly decomposed peat $(\mathrm{Ha})$ in the bottom layer; 3, mollic humic horizon (a); 4, ABg surface horizons with stagnic properties; 5, Bg middle stagnic horizon; 6, Cgk carbonate-bearing clays and clay loam. (c) TE pathways in frozen bog peatlands of continuous permafrost $\left(67^{\circ} \mathrm{N}\right)$. Soil horizons (FAO, 2006): 7, weakly decomposed peat (Hi); 8, partially decomposed peat (He); 9 , humic horizons (AH); 10, cryoturbated frozen stagnic horizon (Bgf); 11, frozen stagnic horizon (BC $\sim$ gf); 12, sedimentary deposits (Cf). In the south, $\mathrm{Me}^{2+}$-DOM complexes are retained by clay, and deep in the soil profile by clay loam with carbonates. In the north, the active layer depth does not exceed the overall thickness of the peat and thus the leachates of ground vegetation and peat layer do not meet mineral horizons during their transit to the river. 
lustrated in Fig. 12. The main difference of WSL permafrostbearing regions from other, Scandinavian, Alaskan, and central Siberian soils is the location of an active (seasonally unfrozen) layer within the organic rather than mineral horizon (Tyrtikov, 1973; Khrenov, 2011). As a result, unlike that of the non-peatland permafrost environments (i.e., Keller et al., 2007; Barker et al., 2014), element mobilization to the river over the full duration of the open-water season occurs essentially from the organic horizon.

We hypothesize three main sources of TEs in rivers from the soil profile shown in Fig. 12a: (i) surface flow (water traveling on the top of the surface and leaching TEs from plant litter and moss/lichen cover); (ii) interstitial soil water of the peat horizons (up to $3 \mathrm{~m}$ thick; Kremenetski et al., 2003), traveling to the river via less permeable clay interface; and (iii) subsurface water, interacting with mineral (sand, clays) horizons. Supplementary to these three main surface water sources is (iv) deep underground water feeding the river during baseflow when the hydraulic pressure of surface waters in the river bed is low (Nikitin and Zemtsov, 1986; Anisimova, 1981; Roux et al., 2015). In the permafrost-free region, all four TE input fluxes are operating during the year. Note that, in this zone, the frozen peat prevents infiltration only during spring melt (Laudon et al., 2007). In the permafrost-bearing regions, the third, shallow subsurface flux from mineral horizons is absent during all seasons and the first and second pathways are realized via suprapermafrost flow (Fig. 13b and c). The soil column is frozen below organic peat layer and the downward-penetrating surface fluids transport DOM and DOM-TE complexes leached from upper soil horizons and litter layer, without DOM sorption onto underlying minerals. This mechanism is evidenced for DOC transport in WSL rivers (Frey and Smith, 2005; Pokrovsky et al., 2015) and the Yenisey Basin (Kawahigashi et al., 2004). It is consistent with the frozen peat context of most western Siberian peat soil profiles.

Indeed, given the 1 to $3 \mathrm{~m}$ thickness of the peat even in the northern part of the WSL (Vasil'evskaya et al., 1986; Kremenetski et al., 2003) and the typical active layer thickness of $50 \pm 30 \mathrm{~cm}$ (Tyrtikov, 1973; Khrenov, 2011; Novikov et al., 2009), in the region of permafrost development, downward-migrating peat soil interstitial solutions will not likely contact the underlying mineral horizon. The consequences of this reduced pathway are twofold. On the one hand, organic complexes of TEs will not adsorb onto clay minerals during DOM-TE migration from the litter horizons through the soil column and further to the river along the permafrost impermeable layer. As a result, the concentration and fluxes of TEs controlled by leaching from moss and lichen cover and topsoil horizons and often originated from atmospheric depositions ( $\mathrm{Mn}, \mathrm{Zn}, \mathrm{Co}, \mathrm{Ni}, \mathrm{Cu}, \mathrm{Pb}, \mathrm{Cd}$ ) will not significantly decrease in the permafrost region relative to the permafrost-free zones. Given the rather uniform distribution of divalent metals in moss and peat of the WSL latitudinal transect (Stepanova et al., 2015), this produces low variation in metal fluxes from 56 to $66^{\circ} \mathrm{N}$ (Table 1).

On the other hand, the lack of fluid contact with the mineral layer may restrict $\mathrm{Fe}$ and other insoluble elements from being leached from silicate minerals. The lack of mineral dissolution brings about a decrease in element concentration northward during active (summer) period, as is seen for Fe (Fig. 2b), Ti (Fig. S3b) and $\mathrm{Zr}$ (not shown). Elements correlated with $\mathrm{Al}$ (see Sect. 3.1) are less affected by watershed latitude, possibly because dissolved $\mathrm{Al}$ is stabilized by organic complexes, equally abundant during top soil/litter leaching in the south and in the north. Here, the coprecipitation step is less pronounced than that for Fe; rather, concomitant mobilization of Al-DOM and TE-DOM complexes may explain positive correlation between mainly insoluble, low-mobility $\mathrm{TE}^{3+}, \mathrm{TE}^{4+}$ and $\mathrm{Al}$ (Table S1).

Concurrent to element mobilization from the soil to the river, a retention of nutrients (Behrendt and Opitz, 2000) or metal pollutants (Vink et al., 1999) in river systems may occur. The degree to which the concepts developed by these authors for western European rivers can be applied to TE transport in low-productivity, pristine WSL rivers that are frozen half the year is uncertain. At quite low annual runoff of the WSL rivers, significant retention of dissolved $\mathrm{Fe}, \mathrm{Mn}$ and $\mathrm{Al}$ by oxyhydroxides and Si by coastal grass and diatoms in the river may occur. However, given that the size of the river (and thus, water residence time in the channel) has an insignificant effect on the concentration of these and other TEs (see Sect. 3.3.1), we argue that there is a negligible impact of TE retention on element transport in WSL rivers.

\subsection{Evolution of TE concentration and fluxes in western Siberian rivers under climate change scenario}

There are four main sources of TEs in the river - surface flow, shallow and deep subsurface flux, and underground water input (Fig. 12). In response to permafrost thaw and active layer depth thickening, the relative role of organic soil vs. mineral subsoil fluxes may change. Specifically, the switch of river feeding from essentially the peat (no. II) to peat + mineral (no. III+II; see Fig. 12) horizon may increase the export of elements whose concentrations are much higher in minerals compared to peat horizons. These are $\mathrm{Fe}, \mathrm{Al}$, all trivalent and tetravalent hydrolysates, $\mathrm{Ba}, \mathrm{V}$ and $\mathrm{Cr}$. At the same time, the surface flux of $\mathrm{Mn}, \mathrm{Zn}, \mathrm{Co}, \mathrm{Ni}, \mathrm{Cu}, \mathrm{Cd}, \mathrm{Pb}$, and, to a lesser extent, $\mathrm{Ba}$ and $\mathrm{Rb}$, essentially controlled by litter and moss leaching, which is mostly pronounced during the spring flood, will remain unaffected. In addition to the change in element source induced by active layer migration, the shift of the permafrost boundary to the north will expose a greater amount of organic peat to infiltrating waters. This will further attenuate the increase in the export flux for TEs whose concentrations in the peat decrease northward (B, Sr, $\mathrm{Mo}, \mathrm{U})$. As a result, the subsoil and shallow groundwater in- 
flux of highly soluble $\mathrm{B}, \mathrm{Li}, \mathrm{Sr}, \mathrm{Mo}, \mathrm{As}, \mathrm{Sb}, \mathrm{W}$ and $\mathrm{U}$ may remain unchanged as the concentrations of these elements in soil mineral horizons progressively decrease northward (see examples in Fig. S16), consistent with the trend in the river water concentration.

Under a climate change scenario, the thickening of the active layer will increase the delivery of insoluble hydrolysates (in the form of organic complexes and organo-ferric colloids) while possibly decreasing the input of divalent metal micronutrients. The downward-migrating organic complexes of the latter may be retained on mineral surfaces and within the clay interlayers (Kaiser et al., 2007; Oosterwoud et al., 2010; Mergelov and Targulian, 2011; Gentsch et al., 2015), similar to that of DOC (Kawahigashi et al., 2004; Pokrovsky et al., 2015). Note, however, that the lack of TE analyses in the permanently frozen peat below the active layer in the northern region of the WSL does not allow for prediction of the consequences of permafrost thaw on TE leaching from previously frozen peat horizons.

Most elements did not yield any statistically significant dependence of annual export fluxes on the latitude. Very few elements demonstrated a systematic and significant (more than a factor of 2) latitudinal trend of fluxes: $\mathrm{Fe}, \mathrm{Zn}$ and $\mathrm{Cd}$ showed a northward increase and $\mathrm{Sr}$, Mo and $\mathrm{U}$ showed a northward decrease. Therefore, the shift of the permafrost boundary northward may decrease the annual fluxes of $\mathrm{Fe}$ and some divalent metals originated from topsoil and mineral horizons while increasing the annual riverine export of Sr, Mo and U.

The change in the hydrological regime in the WSL (Karlsson et al., 2015), in particular the increase in the winter baseflow (Yang et al., 2004; Ye et al., 2009; Serreze et al., 2000) due to the increase in the groundwater feeding (Frey et al., 2007a, b), is likely to increase the export of Fe during winter period. Transport of TEs, linked to Fe during winter baseflow (Al, Ga, REEs, V, Zr, Th), whose concentration increases northward, may also increase; however, the low share of winter flux in the annual transport for these elements does not allow significant (i.e., > 50\%) annual flux modification. In contrast, export of Mn, showing a concentration that is an order of magnitude higher in winter compared to other seasons, may turn out to be significantly affected (by a factor of 2 to 3 ) by the increase of winter flow, equally in the northern and southern regions of the WSL.

The last and most uncertain factor capable modifying TE fluxes in WSL rivers is the increase in the vegetation productivity reported for Arctic river basins (Sturm et al., 2001; Tape et al., 2006; Kirdyanov et al., 2012). On the one hand, this should increase the short-term release of micronutrients (Zn, Mn, Co, Ba) from plant litter, notably during spring flood. A springtime increase in these element concentration northward illustrates the importance of organic matter leaching in the topsoil horizon and transport to the river via suprapermafrost flow. On the other hand, the increase in the plant biomass stock will lead to transient uptake of micronu- trients from organic soil horizons and their storage in the aboveground vegetation. As a result, overall modification of TE fluxes in discontinuous/continuous permafrost zone may be smaller than those projected by simple latitudinal shift.

\section{Conclusions}

A seasonal analysis of dissolved $(<0.45 \mu \mathrm{m})$ TEs in $\sim 60$ rivers of the WSL sampled over a $1500 \mathrm{~km}$ gradient of permafrost, climate and vegetation during three main hydrological seasons demonstrated rather low sensitivity of element concentration and fluxes to the size of the watershed. The season also played a secondary role in determining element concentration pattern and variations among the rivers. PCA and correlation analyses of the full data set identified two possible factors contributing to the observed variability in TEs in rivers and persisting during all sampled seasons. The first factor is the DOM controlling $\mathrm{TE}^{3+}$ and $\mathrm{TE}^{4+}$ migration in the form of organic and organo-mineral colloids. The presence of lakes and bogs on the watershed enhanced the export of insoluble lithogenic TEs, especially during summer and winter. The second factor is the latitude of the watershed translated to the effect of underground water-rock interaction and river feeding via groundwater influx or taliks. This factor was most visible for labile soluble elements such as $\mathrm{Li}, \mathrm{B}, \mathrm{Ca}, \mathrm{Mg}$, DIC, Sr, Mo, As, Sb, W and U. The effect of this factor decreased with the increase in the proportion of lakes and bogs on the watershed. Overall, the major environmental parameters controlling TE concentration in western Siberian rivers can be ranked as following: watershed size < seasons < permafrost gradient. Mn was an exception demonstrating an order of magnitude increase in rivers during winter, regardless of the latitude, which was presumably linked to the change in redox conditions. Insoluble elements, however ( $\mathrm{Fe}, \mathrm{Al}$, and other trivalent hydrolysates), demonstrated a significant increase (up to an order of magnitude) in concentration northward during winter, which was probably linked to their DOM-promoted leaching $(\mathrm{Al})$ from silicate minerals followed by organo-mineral colloid formation.

Within the soil-bedrock profile, the four main reservoirs supplying TEs to the river are the following: (i) plant litter, soil $O_{e}$ horizons, moss and lichen cover, releasing metal micronutrients (Mn, $\mathrm{Zn}, \mathrm{Cu}, \mathrm{Co}, \mathrm{Ni}, \mathrm{Ba}, \mathrm{Rb})$ and atmospherically deposited toxicants $(\mathrm{Cd}, \mathrm{Pb})$ mostly in the form of organic complexes via surface flow, especially visible during spring flood; soil horizon leaching, including both (ii) the peat organic layer and (iii) underlying mineral (clay) layer, providing $\mathrm{Fe}, \mathrm{Al}, \mathrm{TE}^{3+}, \mathrm{TE}^{4+}, \mathrm{V}$, and $\mathrm{Cr}$, mostly as organic complexes and organo-ferric colloids; and finally (iv) underground water reservoirs bearing the signature of water-rock interaction at depth, mostly visible during winter baseflow and connected to the river through taliks (in the permafrostbearing region) and supplying $\mathrm{Li}, \mathrm{B}, \mathrm{Sr}, \mathrm{Mo}, \mathrm{V}, \mathrm{As}, \mathrm{Sb}, \mathrm{W}$, and U. A significant decrease (more than a factor of 10) in 
Sr, Mo and U concentration northward, detectable during all seasons, stems from the decrease in these element concentrations in both peat and underlying mineral horizons as well as the decrease in the underground feeding along the $1500 \mathrm{~km}$ latitudinal profile of the WSL. Under climate warming scenarios, comprising active layer thickening and permafrost boundary shift northward, the surface (i) and underground (ii) contributions to the river are unlikely to be modified. On the other hand, the change in the relative degree of the peat (iv) and mineral (iii) soil leaching to the river may cause the decrease in divalent metal organic complexes and increase in organo-ferric colloids of $\mathrm{TE}^{3+}$ and $\mathrm{TE}^{4+}$ delivery to the river via suprapermafrost flow and hyporheic influx.

\section{Data availability}

The data set of TE concentration sampled in rivers is available at the Research Gate (https://www.researchgate.net/ publication/299390997).

\section{The Supplement related to this article is available online at doi:10.5194/bg-13-1877-2016-supplement.}

Author contributions. Oleg S. Pokrovsky designed the study, performed analyses and wrote the paper; Rinat M. Manasypov and Ivan A. Krickov performed sampling and interpretation; Sergey N. Vorobyev and Sergey N. Kirpotin were responsible for the choice of sampling objects and statistical treatment; Sergey V. Loiko provided the conceptual scheme of element mobilization from the soil to the river; Larisa G. Kolesnichenko supplied the background information on landscape components and permafrost; Sergey G. Kopysov provided hydrological information and water and carried out element flux calculation, analysis and interpretation. All authors participated in field expeditions. Each coauthor viewed and approved the final paper and contributed to writing the manuscript.

Acknowledgements. We acknowledge support from a BIO-GEOCLIM grant (no. 14.B25.31.000) from the Ministry of Education and Science of the Russian Federation and Tomsk State University. O. S. Pokrovsky and R. M. Manasypov were also supported (50\%) by RSF grant no. 15-17-10009, "Evolution of thermokarst ecosystems in the context of climate change".

Edited by: M. Sarin

\section{References}

Abgottspon, F.: Bigalke, M., and Wilcke, W.: Mobilization of trace elements in a carbonatic soil after experimental flooding, Geoderma, 259-260, 156-163, 2015.
Alexeeva, L. B., Strachan, W. M. J., Shluchkova, V. V., Nazarova, A. A., Nikanorov, A. M., Korotova, L. G., and Koreneva, V. I.: Organochlorine pesticide and trace metal monitoring of Russian rivers flowing to the Arctic Ocean: 1990-1996, Mar. Pollut. Bull., 43, 71-85, 2001.

Andersson, P. S., Dahlqvist, R., Ingri, J., and Gustafsson, Ö.: The isotopic composition of $\mathrm{Nd}$ in a boreal river: A reflection of selective weathering and colloidal transport, Geochim. Cosmochim. Ac., 65, 521-527, 2001.

Anisimova, N. P.: Cryohydrochemical Features of Permafrost Zone. (Kriogidrokhimicheskie osobennosti merzloi zony), Nauka, 1981 (in Russian).

Antcibor, I., Eschenbach, A., Zubrzycki, S., Kutzbach, L., Bolshiyanov, D., and Pfeiffer, E.-M.: Trace metal distribution in pristine permafrost-affected soils of the Lena River delta and its hinterland, northern Siberia, Russia, Biogeosciences, 11, 1-15, doi:10.5194/bg-11-1-2014, 2014.

Bagard, M. L., Chabaux, F., Pokrovsky, O. S., Prokushkin, A. S., Viers, J., Dupré, B., and Stille, P. Seasonal variability of element fluxes in two Central Siberian rivers draining high latitude permafrost dominated areas, Geochim. Cosmochim. Ac., 75, 33353357, 2011.

Bagard, M. L., Schmitt, A. D., Chabaux, F., Pokrovsky, O. S., Viers, J., Stille, P., Labolle, F., and Prokushkin, A. S.: Biogeochemistry of stable $\mathrm{Ca}$ and radiogenic $\mathrm{Sr}$ isotopes in larch-covered permafrost-dominated watersheds of Central Siberia, Geochim. Cosmochim. Ac., 114, 169-187, 2013.

Barker, A. J., Douglas, T. A., Jacobson, A. D., McClelland, J. W., Ilgen A. G., Khosh, M. S., Lehn, G. O., and Trainor, T. P.: Late season mobilization of trace metals in two small Alaskan arctic watersheds as a proxy for landscape scale permafrost active layer dynamics, Chem. Geol., 381, 180-193, 2014.

Beaulieu, E., Godderis, Y., Donnadieu, Y., Labat, D., and Roelandt, C.: High sensitivity of the continental-weathering carbon dioxide sink to future climate change, Nature Climate Change, 2, 346349, 2012.

Behrendt, H. and Opitz, D.: Retention of nutrients in river systems: dependence on specific runoff and hydraulic load, Hydrobiologia, 410, 111-122, 2000.

Beilman, D. W., MacDonald, G. M., Smith, L. C., and Reimer, P. J.: Carbon accumulation in peatlands of West Siberia over the last 2000 years, Global Biogeochem. Cy., 23, GB1012, doi:10.1029/2007GB003112, 2009.

Björkvald, L., Buffam, I., Laudon, H., and Mörth, C.-M.: Hydrogeochemistry of $\mathrm{Fe}$ and $\mathrm{Mn}$ in small boreal streams: The role of seasonality, landscape type and scale, Geochim. Cosmochim. Ac., 72, 2789-2804, 2008.

Botch, M. S., Kobak, K. I., Vinson, T. S., and Kolchugina, T. P.: Carbon pools and accumulation in peatlands of the former Soviet Union, Global Biogeochem. Cy., 9, 37-46, doi:10.1029/94GB03156, 1995.

Buffam, I., Laudon, H., Temnerud, J., Mörth, C.-M., and Bishop, K.: Landscape-scale variability of acidity and dissolved organic carbon during spring flood in a boreal stream network, J. Geophys. Res., 112, G01022, doi:10.1029/2006JG000218, 2007.

Cooper, L. W., McClelland, J. W., Holmes, R. M., Raymond, P. A., Gibson, J. J., Guay, C. K., and Peterson, B. J.: Flowweighted values of runoff tracers $\left(\delta^{18} \mathrm{O}, \mathrm{DOC}, \mathrm{Ba}\right.$, alkalin- 
ity) from the six largest Arctic rivers, Geophys. Res. Lett., 35, L18606, doi:10.1029/2008GL035007, 2008.

Dahlqvist, R., Andersson, K., Ingri, J., Larsson, T., Stolpe, B., and Turner, D.: Temporal variations of colloidal carrier phases and associated trace elements in a boreal river, Geochim. Cosmochim. Ac., 71, 5339-5354, 2007.

Dessert, C., Dupré, B., Gaillardet, J., Francois, L. M., and Allégre, C. J.: basalt weathering laws and the impact of basalt weathering on the global carbon cycle, Chem. Geol., 202, 257-273, 2003.

Ershov, E. D.: Geocryology of the USSR, Western Siberia, Nedra, Moscow, 454 pp., 1989.

FAO: Guidelines for soil description, 4th Edn., Rome, FAO, 2006.

Fotiev, C. M.: Taliks and their formations (Taliki i zakonomernosti ix formirovanija), in: Geocryology of the USSR, Western Siberia, edited by: Ershov, E. D., Nedra, Moscow, 72-84, 1989 (in Russian).

Fotiev, C. M.: Formation of taliks of Western Siberia, in : Permanently frozen rocks and cryogenic processes, Moscow, Nauka, 71-78, 1991 (in Russian).

Fraysse, F., Pokrovsky, O. S., and Meunier, J.-D.: Experimental study of terrestrial plant litter interaction with aqueous solutions, Geochim. Cosmochim. Ac., 74, 70-84, 2010.

Frey, K. E. and Smith, L. C.: Amplified carbon release from vast West Siberian peatlands by 2100, Geophys. Res. Lett., 32, L09401, doi:10.1029/2004GL022025, 2005.

Frey, K. E. and Smith, L. C.: How well do we know northern land cover? Comparison of four global vegetation and wetland products with a new ground-truth database for West Siberia, Global Biogeochem. Cy., 21, GB1016, doi:10.1029/2006GB002706, 2007.

Frey, K. E. and McClelland, J. W.: Impacts of permafrost degradation on arctic river biogeochemistry, Hydrol. Process., 23, 169$182,2009$.

Frey, K. E., McClelland, J. W., Holmes, R. M., and Smith, L. C.: Impacts of climate warming and permafrost thaw on the riverine transport of nitrogen and phosphorus to the Kara Sea, J. Geophys. Res., 112, G04S58, doi:10.1029/2006JG000369, 2007a.

Frey, K. E., Siegel, D. I., and Smith, L. C.: Geochemistry of west Siberian streams and their potential response to permafrost degradation, Water Resour. Res., 43, W03406, doi:10.1029/2006WR004902, 2007b.

Gaillardet, J., Millot, R., and Dupré, B.: Chemical denudation rates of the western Canadian orogenic belt: the Stikine terrane, Chem. Geol., 201, 257-279, 2003.

Gaillardet J., Viers J., and Dupré B.: Trace Elements in River Waters, in: Treatise on Geochemistry, Second Edn., edited by: Holland, H. D. and Turekian, K. K., Oxford, Elsevier, 7, 195-235, 2014.

Gentsch, N., Mikutta, R., Alves, R. J. E., Barta, J., Capek, P., Gittel, A., Hugelius, G., Kuhry, P., Lashchinskiy, N., Palmtag, J., Richter, A., Šantrucková, H., Schnecker, J., Shibistova, O., Urich, T., Wild, B., and Guggenberger, G.: Storage and transformation of organic matter fractions in cryoturbated permafrost soils across the Siberian Arctic, Biogeosciences, 12, 4525-4542, doi:10.5194/bg-12-4525-2015, 2015.

Geological composition of the USSR: v. 1, Stratigraphy, Moscow, Gostoptekhizdat, 588 pp., 1958 (in Russian).

Giesler, R., Högberg, M. N., Strobel, B. W., Richter, A., Nordgren, A., and Högberg, P.: Production of dissolved organic carbon and low-molecular weight organic acids in soil solution driven by recent tree photosynthate, Biogeochemistry, 84, 1-12, 2006.

Gordeev, V. V., Martin, J.-M., Sidorov, I. S., and Sidorova, M. V.: A reassessment of the Eurasian river input of water, sediment, major elements, and nutrients to the Arctic Ocean, Am. J. Sci., 296, 664-691, 1996.

Gordeev, V. V., Rachold, V., and Vlasova, I. E.: Geochemical behavior of major and trace elements in suspended particulate material of the Irtysh river, the main tributary of the Ob river, Siberia, Appl. Geochem., 19, 593-610, 2004.

Gustafsson, J.: Visual MINTEQ ver. 3.1., available at: http:// vminteq.lwr.kth.se (last access: 8 August 2015), 2014.

Hindersmann, I. and Mansfeldt, T.: Trace element solubility in a multimetal-contaminated soil as affected by redox conditions, Water Air Soil Pollut., 225, 2158-2178, 2014.

Holmes, R. M., Peterson, B. J., Gordeev, V. V., Zhulidov, A. V., Meybeck, M., Lammers, R. B., and Vörösmarty, C. J.: Flux of nutrients from Russian rivers to the Arctic Ocean: Can we establish a baseline against which to judge future changes?, Water Resour. Res., 36, 2309-2320, 2000.

Holmes, R. M., McClelland, J. W., Peterson, B. J., Tank, S. E., Bulygina, E., Eglinton, T. I., Gordeev, V. V., Gurtovaya, T. Y., Raymond, P. A., Repeta, D. J., Staples, R., Striegl, R. G., Zhulidov, A. V., and Zimov, S. A.: Seasonal and annual fluxes of nutrients and organic matter from large rivers to the Arctic Ocean and surrounding seas, Estuar. Coast., 35, 369-382, doi:10.1007/s12237011-9386-6, 2012.

Holmes, R. M., Coe, M. T., Fiske, G. J., Gurtovaya, T., McClelland, J. W., Shiklomanov, A. I., Spencer, R. G. M., Tank, S. E., and Zhulidov, A. V.: Climate change impacts on the hydrology and biogeochemistry of Arctic Rivers, in: Climatic Changes and Global warming of Inland Waters: Impacts and Mitigation for Ecosystems and Societies, edited by: Goldman, C. R., Kumagi, M., and Robarts, R. D., John Wiley and Sons, 1-26, 2013.

Huh, Y. and Edmond, J. M.: The fluvial geochemistry of the rivers of Eastern Siberia: III. Tributaries of the Lena and Anabar draining the basement terrain of the Siberian Craton and the Trans-Baikal Highlands, Geochim. Cosmochim. Ac., 63, 967-987, 1999.

Huh, Y., Panteleyev, G., Babich, D., Zaitsev, A., and Edmond, J. M.: The fluvial geochemistry of the rivers of Eastern Siberia: II. Tributaries of the Lena, Omoloy, Yana, Indigirka, Kolyma, and Anadyr draining collisional/accretionary zone of the Verkhoyansk and Cherskiy ranges, Geochim. Cosmochim. Ac., 62, 20532075, 1998.

Huser, B. J., Köhler, S. J., Wilander, A., Johansson, K., and Fölster, J.: Temporal and spatial trends for trace metals in streams and rivers across Sweden (1996-2009), Biogeosciences, 8, 18131823, doi:10.5194/bg-8-1813-2011, 2011.

Huser, B. J., Fölster, J., and Köhler, S. J.: Lead, zinc, and chromium concentrations in acidic headwater streams in Sweden explained by chemical, climatic, and land-use variations, Biogeosciences, 9, 4323-4335, doi:10.5194/bg-9-4323-2012, 2012.

Ingri, J., Widerlund, A., Land, M., Gustafsson, Ö., Andersson, P. S., and Öhlander, B.: Temporal variations in the fractionation of the rare earth elements in a boreal river, the role of colloidal particles, Chem. Geol., 166, 23-45, 2000.

Ingri, J., Widerlund, A., and Land, M.: Geochemistry of major elements in a pristine boreal river system, Hydrological compartments and flow paths, Aquat. Geochem., 11, 57-88, 2005. 
Kaiser, C., Meyer, H., Biasi, C., Rusalimova, O., Barsukov, P., and Richter, A.: Conservation of soil organic matter through cryoturbation in arctic soils in Siberia, J. Geophys. Res., 112, 9-17, 2007.

Karlsson, J. M., Jaramillo, F., and Destouni, G.: Hydro-climatic and lake change patterns in Arctic permafrost and non-permafrost areas, J. Hydrol., 529, 134-145, 2015.

Kawahigashi, M., Kaiser, K., Kalbitz, K., Rodionov, A., and Guggenberger, G.: Dissolved organic matter in small streams along a gradient from discontinuous to continuous permafrost, Glob. Change Biol., 10, 1576-1586, doi:10.1111/j.13652486.2004.00827.x, 2004.

Keller, K., Blum, J. D., and Kling, G. W.: Geochemistry of soils and streams on surfaces of varying ages in arctic Alaska, Arct. Antarct. Alp. Res., 39, 84-98, 2007.

Keller, K., Blum, J. D., and Kling, G. W.: Stream geochemistry as an indicator of increasing permafrost thaw depth in an arctic watershed, Chem. Geol., 273, 76-81, 2010.

Kirdyanov, A. V., Hagedorn, F., Knorre, A. A., Fedotova, E. V., Vaganov, E. A., Naurzbaev, M. M., Moiseev, P. A., and Rigling, A.: 20th century tree-line advance and vegetation changes along an altitudinal transect in Putorana Mountains, northern Siberia, Boreas, 41, 56-67, 2012.

Khrenov, V. Y.: Soils of cryolithozone of western Siberia: Morphology, physico-chemical properties and geochemistry, Nauka, Moscow, 214 pp., 2011 (in Russian).

Kremenetski, K. V., Velichko, A. A., Borisova, O. K., MacDonald, G. M., Smith, L. C., Frey, K. E., and Orlova, L. A.: Peatlands of the West Siberian Lowlands: Current knowledge on zonation, carbon content, and Late Quaternary history, Quaternary Sci. Rev., 22, 703-723, 2003.

Laudon, H., Sjoblom, V., Buffam, I., Seibert, J., and Morth, M.: The role of catchment scale and landscape characteristics for runoff generation of boreal streams, J. Hydrol., 344, 198-209, 2007.

Laudon, H., Taberman, I., Agren, A., Futter, M., OttossonLofvenius, M., and Bishop, K.: The Kryckland catchment study - a flagship infrastructure for hydrology, biogeochemistry, and climate research in the boreal landscape, Water Resour. Res., 49, 7154-7158, 2013.

Lidman, F., Morth, C. M., Bjorkvald, L., and Laudon, H.: Selenium dynamics in boreal streams: The role of wetlands and changing groundwater tables, Environ. Sci. Technol., 45, 2677-2683, 2011.

Lidman, F., Mörth, C. M., and Laudon, H.: Landscape control of uranium and thorium in boreal streams - spatiotemporal variability and the role of wetlands, Biogeosciences, 9, 4773-4785, doi:10.5194/bg-9-4773-2012, 2012.

Lidman, F., Kohler, S. J., Morth, C.-M., and Laudon, H.: Metal transport in the boreal landscape - the role of wetlands and the affinity for organic matter, Environ. Sci. Technol., 48, 37833790, 2014.

Lyvén, B., Hassellöv, M., Turner, D. R., Haraldsson, C., and Andersson, K.: Competition between iron- and carbon-based colloidal carriers for trace metals in a freshwater assessed using flow field-flow fractionation coupled to ICPMS, Geochim. Cosmochim. Ac., 67, 3791-3802, 2003.

MacMillan, G. A., Girard, C., Chételat, J., Laurion, I., and Amyot, M.: High methylmercury in arctic and subarctic ponds is related to nutrient Levels in the warming Eastern Canadian Arctic, Envi- ron. Sci. Technol., 49, 7743-7753, doi:10.1021/acs.est.5b00763, 2015.

Manasypov, R. M., Pokrovsky, O. S., Kirpotin, S. N., and Shirokova, L. S.: Thermokarst lake waters across the permafrost zones of western Siberia, The Cryosphere, 8, 1177-1193, doi:10.5194/tc-8-1177-2014, 2014.

Manasypov, R. M., Vorobyev, S. N., Loiko, S. V., Kritzkov, I. V., Shirokova, L. S., Shevchenko, V. P., Kirpotin, S. N., Kulizhsky, S. P., Kolesnichenko, L. G., Zemtzov, V. A., Sinkinov, V. V., and Pokrovsky, O. S.: Seasonal dynamics of organic carbon and metals in thermokarst lakes from the discontinuous permafrost zone of western Siberia, Biogeosciences, 12, 30093028, doi:10.5194/bg-12-3009-2015, 2015.

McClelland, J. W., Déry, S. J., Peterson, B. J., Holmes, R. M., and Wood, E. F.: A pan-Arctic evaluation of changes in river discharge during the latter half of the 20th century, Geophys. Res. Lett., 33, L06715, doi:10.1029/2006GL025753, 2006.

McClelland, J. W., Tank, S. E., Spencer, R. G. M., and Shiklomanov, A. I.: Coordination and sustainability of river observing activities in the Arctic, Arctic, 68, doi:10.14430/arctic4448, 2015.

Mergelov, N. and Targulian, V.: Accumulation of organic matter in the mineral layers of permafrost-affected soils of coastal lowlands in East Siberia, Eurasian Soil Sci., 44, 249-260, 2011.

Michel, F. A. and Vaneverdingen, R. O.: Changes in hydrologic regimes in permafrost regions due to climate-change, Permafrost Periglac., 5, 191-195, 1994.

Millot, R., Gaillardet, J., Dupré, B., and Allègre, C. J.: Northern latitude chemical weathering rates: Clues from the Mackenzie River Basin, Canada, Geochim. Cosmochim. Ac., 67, 13051329, 2003.

Moran, S. B. and Woods, W. L.: Cd, Cr, $\mathrm{Cu}, \mathrm{Ni}$ and $\mathrm{Pb}$ in the water column and sediments of the Ob-Irtysh Rivers, Russia, Mar. Pollut. Bull., 35, 270-279, 1997.

Neubauer, E., Kohler, S. J., von der Kammer, F., Laudon, H., and Hofmann, T.: Effect of $\mathrm{pH}$ and stream order on iron and arsenic speciation in boreal catchments, Environ. Sci. Technol., 47, 7120-7128, 2013.

Nikitin, S. P. and Zemtsov, V. A.: The variability of hydrological parameters of western Siberia, Nauka, Novosibirsk, 204 pp., 1986 (in Russian)

Novikov, S. M., Moskvin, Y. P., Trofimov, S. A., Usova, L. I., Batuev, V. I., Tumanovskaya, S. M., Smirnova, V. P., Markov, M. L., Korotkevicth, A. E., and Potapova, T. M.: Hydrology of bog territories of the permafrost zone of western Siberia, BBM publ. House, St. Petersbourg, 535 pp., 2009 (in Russian).

Oliva, P., Viers, J., and Dupré, B.: Chemical weathering in granitic environments, Chem. Geol., 202, 225-256, 2003.

Oni, S. K., Futter, M. N., Bishop, K., Köhler, S. J., OttossonLöfvenius, M., and Laudon, H.: Long-term patterns in dissolved organic carbon, major elements and trace metals in boreal headwater catchments: trends, mechanisms and heterogeneity, Biogeosciences, 10, 2315-2330, doi:10.5194/bg-10-2315-2013, 2013.

Oosterwoud, M. R., Temminghoff, E. J. M., and van der Zee, S. E. A. T. M.: Quantification of DOC concentrations in relation with soil properties of soils in tundra and taiga of Northern European Russia, Biogeosciences Discuss., 7, 3189-3226, doi:10.5194/bgd-7-3189-2010, 2010. 
Pokrovsky, O. S., Schott, J., and Dupre, B.: Trace element fractionation and transport in boreal rivers and soil porewaters of permafrost-dominated basaltic terrain in Central Siberia, Geochim. Cosmochim. Ac., 70, 3239-3260, 2006.

Pokrovsky, O. S., Viers, J., Shirokova, L. S., Shevchenko, V. P., Filipov, A. S., and Dupré, B.: Dissolved, suspended, and colloidal fluxes of organic carbon, major and trace elements in Severnaya Dvina River and its tributary, Chem. Geol., 273, 136-149, 2010.

Pokrovsky, O. S., Shirokova, L. S., Kirpotin, S. N., Audry, S., Viers, J., and Dupré, B.: Effect of permafrost thawing on organic carbon and trace element colloidal speciation in the thermokarst lakes of western Siberia, Biogeosciences, 8, 565-583, doi:10.5194/bg-8565-2011, 2011.

Pokrovsky, O. S., Viers, J., Dupré, B., Chabaux, F., Gaillardet, J., Audry, S., Prokushkin, A. S., Shirokova, L. S., Kirpotin, S. N., Lapitsky, S. A., and Shevchenko, V. P.: Biogeochemistry of carbon, major and trace elements in watersheds of Northern Eurasia drained to the Arctic Ocean: The change of fluxes, sources and mechanisms under the climate warming prospective, C. R. Geosci., 344, 663-677, 2012.

Pokrovsky, O. S., Shirokova, L. S., Kirpotin, S. N., Kulizhsky, S. P., and Vorobiev, S. N.: Impact of western Siberia heat wave 2012 on greenhouse gases and trace metal concentration in thaw lakes of discontinuous permafrost zone, Biogeosciences, 10, 5349-5365, doi:10.5194/bg-10-5349-2013, 2013.

Pokrovsky, O. S., Manasypov, R. M., Loiko, S., Shirokova, L. S., Krickov, I. A., Pokrovsky, B. G., Kolesnichenko, L. G., Kopysov, S. G., Zemtzov, V. A., Kulizhsky, S. P., Vorobyev, S. N., and Kirpotin, S. N.: Permafrost coverage, watershed area and season control of dissolved carbon and major elements in western Siberian rivers, Biogeosciences, 12, 6301-6320, doi:10.5194/bg12-6301-2015, 2015.

Pontér, C., Ingri, J., Burmann, J., and Boström, K.: Temporal variations in dissolved and suspended iron and manganese in the Kalix River, northern Sweden, Chem. Geol. 81, 121-131, 1990.

Pontér, C., Ingri, J., and Boström, K.: Geochemistry of manganese in the Kalix River, northern Sweden, Geochim. Cosmochim. Ac., 56, 1485-1494, 1992.

Porcelli, D., Andersson, P. S., Wasserburg, G. J., Ingri, J., and Baskaran, M.: The importance of colloids and mires for the transport of uranium isotopes through the Kalix River watershed and Baltic Sea, Geochim. Cosmochim. Ac., 61, 4095-4113, 1997.

Reeder, S. W., Hitchon, B., and Levinson, A. A.: Hydrogeochemistry of the surface waters of the Mackenzie River drainage basin, Canada - I, Factors controlling inorganic composition, Geochim. Cosmochim. Ac., 36, 826-865, 1972.

Rember, R. D. and Trefry, J. H.: Increased concentrations of dissolved trace metals and organic carbon during snowmelt in rivers of the Alaskan Arctic, Geochim. Cosmochim. Ac., 68, 477-489, 2004.

Roux, N., Grenier, C., and Costard, F.: Experimental and numerical simulations of heat transfers between flowing water and a frozen porous medium, Geophysical Research Abstracts 17, EGU20158860, 2015.

Serreze, M. C., Walsh, J. E., Chapin, E., Osterkamp, T., Dyugerov, M., Romanovsky, V., Oechel, W. C., Morison, J., Zhang, T., and Barry, R. G.: Observation evidence of recent change in the northern high-latitude environment, Climatic Change, 46, 159-207, 2000.
Seyler, P., Pinelli, M., and Boaventura, G. R.: A first quantitative estimate of trace metal fluxes from Amazon river and its main tributaries, Journal Physique IV (Proceedings), 107, 1213-1218, doi:10.1051/jp4:20030519, 2003.

Shirokova, L. S., Pokrovsky, O. S., Kirpotin, S. N., Desmukh, C., Pokrovsky, B. G., Audry, S., and Viers, J.: Biogeochemistry of organic carbon, $\mathrm{CO}_{2}, \mathrm{CH}_{4}$, and trace elements in thermokarst water bodies in discontinuous permafrost zones of Western Siberia, Biogeochemistry, 113, 573-593, 2013.

Smith, L. C., Macdonald, G. M., Velichko, A. A., Beilman, D. W., Borisova, O. K., Frey, K. E., Kremenetsky, K. V., and Sheng, Y.: Siberian peatlands as a net carbon sink and global methane source since the early Holocene, Science, 303, 353-356, 2004.

Stepanova, V. M., Pokrovsky, O. S., Viers, J., MironychevaTokareva, N. P. Kosykh, N. P., and Vishnyakova, E. K.: Major and trace elements in peat profiles in Western Siberia: impact of the landscape context, latitude and permafrost coverage, Appl. Geochem., 53, 53-70, 2015.

Stolpe, B., Guo, L., Shiller, A. M., and Aiken, G. R.: Abundance, size distribution and trace-element binding of organic and iron-rich nanocolloids in Alaskan rivers, as revealed by fieldflow fractionation and ICP-MS, Geochim. Cosmochim. Ac., 105, 221-239, 2013.

Sturm, M., Racine, C., and Tape, K.: Increasing shrub abundance in the Arctic, Nature, 411, 546-547, 2001.

Sugai, S. F. and Burrell, D. C.: Transport of Dissolved Organic Carbon, Nutrients, and Trace Metals from the Wilson and Blossom Rivers to Smeaton Bay, Southeast Alaska, Can. J. Fish. Aquat. Sci., 41, 180-190, doi:10.1139/f84-019, 1984.

Tank, S. E., Raymond, P. A., Striegl, R. G., McClelland, J. W., Holmes, R. M., Fiske, G. J., and Peterson, B. J.: A land-to-ocean perspective on the magnitude, source and implication of DIC flux from major Arctic rivers to the Arctic Ocean, Global Biogeochem. Cy., 26, GB4018, doi:10.1029/2011GB004192, 2012.

Tape, K., Sturm, M., and Racine, C.: The evidence for shrub expansion in Northern Alaska and the Pan-Arctic, Glob. Change Biol., 12, 686-702, doi:10.1111/j.1365-2486.2006.01128.x, 2006.

Tarvainen, T., Lahermo P., and Mannio J.: Sources of trace metals in streams and headwater lakes in Finland, Water Air Soil Pollut., 94, 1-32, 1997.

Temnerud, J., Düker, A., Karlsson, S., Allard, B., Bishop, K., Fölster, J., and Köhler, S.: Spatial patterns of some trace elements in four Swedish stream networks, Biogeosciences, 10, 1407-1423, doi:10.5194/bg-10-1407-2013, 2013.

Tyrtikov, A. P.: Thawing of soils in tundra of western Siberia, in: Natural environment of western Siberia, edited by: Popov, A. I., Issue 3, Izd-vo MG, Moscow, 160-169, 1973 (in Russian).

Vasil'evskaya, V. D., Ivanov, V. V., and Bogatyrev, L. G.: Soils of North of western Siberia, Moscow University Publ. House, Moscow, 228 pp., 1986 (in Russian).

Vasyukova, E. V., Pokrovsky, O. S., Viers, J., Oliva, P., Dupré, B., Martin, F., and Candadaup, F.: Trace elements in organic- and iron-rich surficial fluids of the boreal zone: Assessing colloidal forms via dialysis and ultrafiltration, Geochim. Cosmochim. Ac., 74, 449-468, 2010.

Vink, R. J., Behrendt, H., and Salomons, W.: Point and diffuse source analysis of heavy metals in the Elbe drainage area: Comparing heavy metal emissions with transported river loads, Hydrobiologia, 410, 307-314, 1999. 
Vonk, J. E., Tank, S. E., Bowden, W. B., Laurion, I., Vincent, W. F., Alekseychik, P., Amyot, M., Billet, M. F., Canário, J., Cory, R. M., Deshpande, B. N., Helbig, M., Jammet, M., Karlsson, J., Larouche, J., MacMillan, G., Rautio, M., Walter Anthony, K. M., and Wickland, K. P.: Reviews and syntheses: Effects of permafrost thaw on Arctic aquatic ecosystems, Biogeosciences, 12, 7129-7167, doi:10.5194/bg-12-7129-2015, 2015.

Vorobyev, S. N., Pokrovsky, O. S., Kirpotin, S. N., Kolesnichenko, L. G., Shirokova, L. S., and Manasypov, R. M.: Flood zone biogeochemistry of the Ob' River middle course, Appl. Geochem., 63, 133-145, 2015.

Wadleigh, M. A., Veizer, J., and Brooks, C.: Strontium and its isotopes in Canadian Rivers - fluxes and global implications, Geochim. Cosmochim. Ac., 49, 1727-1736, 1985.

Walvoord, M. A. and Striegl, R. G.: Increased groundwater to stream discharge from permafrost thawing in the Yukon River basin: Potential impacts on lateral export of carbon and nitrogen, J. Geophys. Res., 34, L12402, doi:10.1029/2007GL030216, 2007.

Walvoord, M. A., Voss, C. I., and Wellman, T. P.: Influence of permafrost distribution on groundwater flow in the context of climate-driven permafrost thaw: Example from Yukon Flats Basin, Alaska, United States, Water Resour. Res., 48, W07524, doi:10.1029/2011WR011595, 2012.

Wällstedt, T., Björkvald, L., and Gustafsson, J. P.: Increasing concentrations of arsenic and vanadium in (southern) Swedish streams, Appl. Geochem., 25, 1162-1175, 2010.

Weber, F. A., Voegelin, A., and Kretzschmar, R.: Multi-metal contaminant dynamics in temporarily flooded soil under sulfate limitation, Geochim. Cosmochim. Ac., 73, 5513-5527, 2009.
White, D., Hinzman, L., Alessa, L., Cassano, J., Chambers, M., Falkner, K., Francis, J., Gutowski Jr., W. J., Holland, M., Holmes, R. M., Huntington, H., Kane, D., Kliskey, A., Lee, C., McClelland, J., Peterson, B., Rupp, T. S., Straneo, F., Steele, M., Woodgate, R., Yang, D., Yoshikawa, K., and Zhang T.: The arctic freshwater system: Changes and impacts, J. Geophys. Res., 112, G04S54, doi:10.1029/2006JG000353, 2007.

Yang, D., Ye, B., and Shiklomanov, A.: Discharge characteristics and changes over the Ob River watershed in Siberia, J. Hydrometeorol., 5, 595-610, 2004.

Yastrebov, A. A. and Ivanov, Y. K.: Fresh groundwater regional dynamics of the Yamal-Nenets autonomous region, Lithosphere (Litosfere), 5, 99-112, 2008 (in Russian).

Ye, B., Yang, D., Zhang, Z., and Kane, D. L.: Variation of hydrological regime with permafrost coverage over Lena basin in Siberia, J. Geophys. Res., 114, D07102, doi:10.1029/2008JD010537, 2009.

Yeghicheyan, D., Bossy, C., Bouhnik Le Coz, M., Douchet, Ch., Granier, G., Heimburger, A., Lacan, F., Lanzanova, A., Rousseau, T. C. C., Seidel, J.-L., Tharaud, M., Candaudap, F., Chmeleff, J., Cloquet, C., Delpoux, S., Labatut, M., Losno, R., Pradoux, C., Sivry, Y., and Sonke, J. E.: A Compilation of Silicon, Rare Earth Element and Twenty-One other Trace Element Concentrations in the Natural River Water Reference Material SLRS-5 (NRC-CNRC), Geostand. Geoanal. Res., 37, 449-467, doi:10.1111/j.1751-908X.2013.00232.x, 2013.

Zhil, I. M. and Alushkinskaya, N. M.: Resources of Surface Waters USSR Vol. III, Northern regions, Gidrometeoizdat, Leningrad, 633 pp., 1972. 